University of California, Hastings College of the Law UC Hastings Scholarship Repository

Faculty Scholarship

2003

\title{
Do International Trade Institutions Contribute to Economic Growth and Development?
}

Joel R. Paul

UC Hastings College of the Law, paulj@uchastings.edu

Follow this and additional works at: http://repository.uchastings.edu/faculty_scholarship

Part of the International Trade Law Commons

\section{Recommended Citation}

Joel R. Paul, Do International Trade Institutions Contribute to Economic Growth and Development?, 44 Va. J. Int'l L. 285 (2003). Available at: http://repository.uchastings.edu/faculty_scholarship/627

This Article is brought to you for free and open access by UC Hastings Scholarship Repository. It has been accepted for inclusion in Faculty Scholarship by an authorized administrator of UC Hastings Scholarship Repository. For more information, please contact marcusc@uchastings.edu. 


\section{Faculty Publications \\ UC Hastings College of the Law Library}

Author: Joel R. Paul

Source: $\quad$ Virginia Journal of International Law

Citation: $\quad 44$ Va. J. Int'I L. 285 (2003).

Title: Do International Trade Institutions Contribute to Economic Growth and Development?

Originally published in VIRGINIA JOURNAL OF INTERNATIONAL LAW. This article is reprinted with permission from VIRGINIA JOURNAL OF INTERNATIONAL LAW and University of Virginia School of Law. 


\title{
Do International Trade Institutions Contribute to Economic Growth and Development?
}

\author{
JOEL R. PAUL
}

\section{TABLE OF CONTENTS}

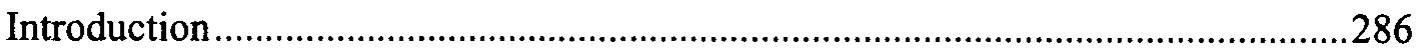

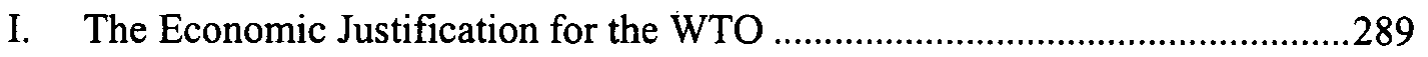

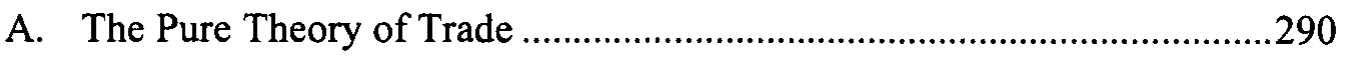

B The Pure Theory in an Imperfect Market ...............................................292

C. Empirical Measurements of the Gains from Trade and Sunk Costs.........298

D. Social Welfare Gains and Losses from Trade ..........................................301

E. Constructed Comparative Advantage ………….........................................305

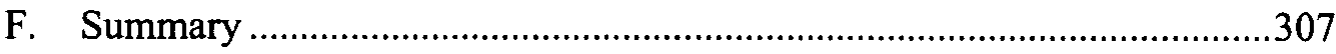

II. Distributional Consequences of International Trade ......................................308

III. Trade in the Presence of Market Failures or Distortions ....................................320

A. GATT Requires Liberalization, Even in the Presence of External

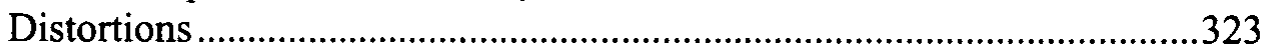

B. GATT Authorizes Certain Protectionist Measures......................................324

C. The GATT Permits Certain Trade Preferences that Distort

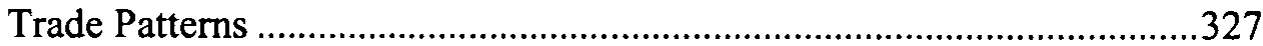

D. The WTO Mandates that Countries Undertake Measures that Limit

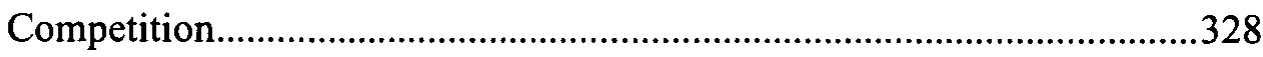

E. Are Antidumping Duties and Countervailing Duties an Appropriate Response to External Market Failures and Distortions? .............................330

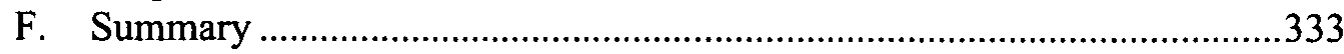

IV. How International Trade Institutions Contribute to Policy Coordination

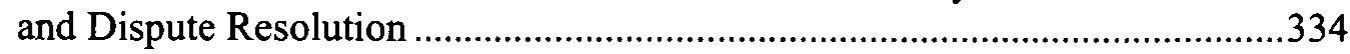

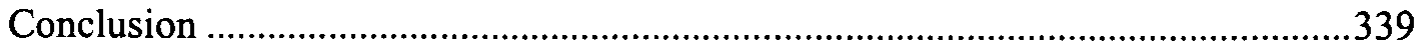

* Professor, University of California Hastings College of the Law. I am grateful for the research assistance of my students Jean-Paul Buchanan, Daniel Erlihkman, Wadih Helou, and Christopher Nolan and the librarian assistance of Julie Horst and Vince Moyer. I appreciate the useful comments of Professors Robin Feldman, Eleanor Fox, David Kennedy, and Joseph Weiler on an early draft of this article. 


\section{INTRODUCTION}

Should the expansion of international trade institutions, like the World Trade Organization (WTO), the North American Free Trade Area (NAFTA), or the Free Trade Agreement of the Americas (FTAA), be linked to new standards protecting labor, human rights, and the environment? Linkage remains one of the principal issues in the negotiations for a Free Trade Area of the Americas (FTAA) and in the current WTO round. To many people it appears that linking trade to other social policies is mixing apples and oranges. If the function of international trade institutions is to promote economic growth through a more efficient allocation of resources, it may seem unnatural to graft onto those institutions provisions regulating labor, human rights, and environmental standards. The argument for linkage must challenge the underlying assumption that international trade institutions really promote a more efficient market.

Proponents of trade liberalization routinely defend international trade institutions as engines of economic growth that benefit everyone. The justificatory rhetoric of trade institutions is so familiar that it operates as a background assumption of most informed persons. The purposes of the WTO, stated in the opening paragraph of its charter, include "raising standards of living, ensuring full employment and a large and steadily growing volume of real income and effective demand, and expanding the production of and trade in goods and services, while allowing for the optimal use of the world's resources." Defenders of the WTO and NAFTA explicitly argue that trade leads to economic growth according to the theory of comparative advantage. In seeking Trade Promotion Authority (TPA) from Congress to negotiate a new FTAA, President George W. Bush argued, "Open trade fuels the engines of economic growth that creates new jobs and new income. It applies the power of markets to the needs of the poor."2

It is not only political leaders who invoke the economic justification for international trade organizations. John Jackson, one of the leading legal authorities on the WTO and the General Agreement on Tariffs and Trade (GATT), writes that the "starting point for any discussion of policy for the international economic system of today is the notion of

1. Final Act Embodying the Results of the Uruguay Round of Trade Negotiations, Apr. 15, 1994, 33 I.L.M. 1125, 1144 [hereinafter Final Act].

2. OfFice of THE United States TRade RePresentative, 2002 Trade Policy Agenda AND 2001 ANNUAL REPORT OF THE PRESIDENT OF THE UNITED STATES ON THE TRADE AGREEMENTS PROGRAM (March 2002), available at http://www.ustr.gov/reports.2002.html. 
"liberal trade...", Jackson cites numerous legal documents supporting the proposition that the WTO is a source of economic growth based on the theory of comparative advantage. ${ }^{4}$

How trade proponents justify trade institutions matters because their justificatory rhetoric leads to certain policy conclusions about the appropriate function of those institutions. Opponents of linkage argue that international trade institutions promote economic growth by reducing barriers to trade, and that burdening these institutions with other responsibilities for promoting non-economic values confuses their mission and distorts economic efficiency.

This paper examines the theory and operation of international trade law and institutions and questions whether these institutions promote economic growth as proponents claim. I will argue that the proponents of trade have not satisfied the burden of proving that international trade institutions promote economic growth. Although I will focus on the WTO as the most important institution in international trade, much of my critique applies as well to regional trade agreements (RTAs). I will use the term "WTO" in the broadest sense to refer not merely to the organization and its charter, but also to the 1994 GATT, which applies to all WTO members. ${ }^{5}$ I argue that international trade law and institutions are internally inconsistent and may distort economic efficiency and result in negative growth under some circumstances. To the extent that international trade institutions have promoted economic growth, they have often contributed to a growing disparity of wealth within and between the industrialized and developing countries.

My purpose is not to defend protectionism, nor to oppose trade institutions like the WTO. The WTO has great value as a political institution fostering cooperation and conflict resolution through the dispute-settlement procedure, even if it does not necessarily promote significant economic growth. Rather, I argue that we should abandon the false justificatory rhetoric of economic growth and acknowledge the political policymaking function of trade institutions. Promoting labor standards, human rights, and a sustainable environment are appropriate goals for international trade institutions to pursue.

Part One discusses the economic justification for the WTO. WTO

3. JOHN H. JACKSON, THE WORLD TRADING SYSTEM 11 (1997).

4. Id. at $12-18$.

5. I will use the term "GATT" here to include the associated multilateral and plurilateral agreements negotiated with the 1994 GATT, such as the General Agreement on Trade in Services (GATS), the Agreement on Technical Barriers to Trade (TBT), the Agreement on Sanitary and Phyto-Sanitary measures (SPS), and the Agreement on Trade-Related Intellectual Property Rights (TRIPS). 
proponents generally argue that according to the theory of comparative advantage, the WTO maximizes world welfare by lowering trade barriers. First, I examine the assumptions underlying the theory of comparative advantage and argue that these assumptions rarely conform to the realities of the contemporary international market. In the absence of these conditions, comparative advantage cannot show that trade leads to a more efficient allocation of resources. Second, empirical studies of the gains from trade cast doubt on the assumption that trade liberalization necessarily leads to worldwide economic growth. Indeed the gains from trade are often less than the sunk costs from lost resources that result from import competition. Third, even if trade liberalization creates economic growth in some circumstances, there is reason to doubt it improves social welfare. Fourth, the argument for trade liberalization ignores the important role that government plays in determining comparative advantage. In particular, government interference in the market often constructs comparative advantage.

Part Two examines the impact of trade and trade institutions on global income distribution. The proponents of the WTO and the FTAA claim that the benefits of trade are shared equally by the poorest countries and households. Part Two reviews the empirical studies and the issues raised by their methodologies. I conclude that the weight of the evidence suggests that globalization has increased income inequality both among countries and within countries.

Neo-liberal economists acknowledge that international markets are distorted, and according to the theory of the second best, they prescribe government intervention in the market to correct some of these distortions. Under some circumstances, neo-liberal economists would favor trade regulation in response to external market failures. Part Three argues that the legal obligations of the GATT are both inconsistent with its economic justification and a constraint on governments from taking the measures necessary to correct market failures and distortions. As a consequence, the rule structure of the GATT itself distorts the market or perpetuates market failures and may retard economic growth.

Part Four offers a strong defense for international trade institutions as organs of conflict resolution and policy reconciliation. The WTO, in particular, has demonstrated remarkable effectiveness in resolving conflict, avoiding trade wars, and stabilizing regimes. I conclude that institutions like the WTO can have greater utility as political institutions than as engines of economic growth. Accordingly, international trade institutions are well suited to undertake policy measures for the protection of labor, human rights, and the environment. 


\section{THE ECONOMIC JUSTIFICATION FOR THE WTO}

Proponents of the WTO routinely argue that the organization creates economic gains for all countries and for all Americans. ${ }^{6}$ For example, the U.S. Trade Representative Charlotte Barshefsky defended U.S. support for the WTO in terms of the economic benefits for Americans:

Our work at the WTO, to begin with, rests upon a foundation of American commitment to open markets, freer trade, and the rule of law in world commerce.

...In one sense, this is a matter of economic logic. Open markets abroad enable us to export, and exports are essential to a strong domestic economy.

...Imports create the choice, price, and competition that raise family living standards-for all families, but most especially the poor-and help to dampen inflation.... And they give businesses access to inputs - raw materials, parts, business equipment--that reduce costs and thus improve efficiency and competitiveness. ${ }^{7}$

Defending the WTO in terms of the economic benefits for Americans is intended to win popular political support at home for continued negotiations under the WTO. We are also told that the WTO creates economic growth in developing and industrialized countries alike. As one WTO document explains:

Trade, when it is allowed to flow freely, fosters economic growth. It encourages specialization, which can lead to greater gains in productivity and efficiency. It means countries can concentrate their resources on producing the goods they make best and importing goods that are more efficiently produced elsewhere. A more open world trading system means all countries benefit from access to the 6 billion customers in the global marketplace. ${ }^{8}$

6. E.g., COUNCIL OF ECONOMIC AdVISORS, TRADE AND THE AMERICAN ECONOMY: THE CASE FOR TRADE PROMOTION AUTHORITY (Feb. 12, 2002), available at http://www.whitehouse.gov/cea.pubs.html. The CEA argues that the Trade Promotion Authority, (TPA), would boost GDP. According to the CEA some studies estimated that 1994 GATT Round could produce an annual income gain of $\$ 600-800$ per household of four.

7. Ambassador Charlene Barshefsky, U.S. Trade Policy and the Trading System, Address Before the Brandeis University Graduate School of International Economics and Finance (April 13, 2000), available at http://www.ustr.gov/speech-test/barshefsky/barshefsky_79.pdf.

8. THE WTO... Why IT MATTERS: A GUIDE FOR OfFicials, Legislators, Civil SOCIETY AND ALL THOSE INTERESTED IN INTERNATIONAL TRADE AND GLOBAL GOVERNANCE, RESOURCE BOOKLET FOR THE 4TH WTO MINISTERIAL CONFERENCE 6 (2001), available at http://www.wto.org/english/thewto_e/min01_e/ wto_matters_e.pdf. 
These economic arguments are often combined. For example, during the congressional debates over whether the United States should adopt the Uruguay Round Agreements and join the WTO, members of both houses of Congress argued that the WTO would create economic benefits for everyone. Senator DeConcini, for instance, warned his colleagues that the failure of the United States to join the WTO and the 1994 GATT would "bring international economic growth to a grinding halt." Senator Gramm described the GATT as a "wealth machine,"10 and Senator Daschle defended the Uruguay Round Agreement as "first and foremost an indispensable tool for facilitating economic growth and job creation in our country." 11

The economic justification for international trade institutions of course derives from the theory of comparative advantage. Throughout the debates on the WTO in both houses of Congress, members arguing on both sides of the issue frequently argued that the WTO would facilitate the operation of comparative advantage. Neo-liberal economists have qualified the theory of comparative advantage in significant respects, and they concede that the theory may not be relevant to many contemporary market circumstances. Nevertheless, there appears to be a disconnect between the more nuanced treatment of the theory by economists, and the bold unqualified assertions of political leaders, international lawyers, legal scholars, and governments. For this reason, it is worthwhile to re-examine the theory.

\section{A. The Pure Theory of Trade}

Writing in 1776, Adam Smith challenged the conventional faith in mercantilism: the policy of protecting a domestic industry from less expensive imports. ${ }^{12}$ Mercantilism rested on the idea that a country's wealth was increased by exporting more than it imported. Smith believed that nations possess certain natural advantages in production. England's cool climate produced wool more efficiently than Italy's sunny climate, which was better suited to produce grapes. England could be said to enjoy an absolute advantage in the production of wool, just as Italy enjoyed an absolute advantage in the production of wine. Smith argued that in the absence of any trade barriers, free-market competition would lead consumers to buy their wool more cheaply from England and their wine more cheaply from Italy. Smith concluded that

9. 140 CONG. REC. S15,271, S15,296 (1994).

10. Id. at 299.

11. Id. at 348 .

12. ADAM SMith, The Wealth OF NaTions (1776). 
mercantilism reduced a nation's wealth by denying a country the benefits of specialization. The theory of absolute advantage worked only if a country enjoyed an absolute advantage over other countries in the production of a specific good. It failed to explain how free trade could benefit a country that did not possess any absolute advantage in production.

In 1817, David Ricardo significantly advanced Smith's argument for free trade by postulating the theory of comparative advantage. Ricardo showed that it did not matter whether a country had an absolute advantage in the production of any good. Instead, he focused on a country's comparative advantage. Rather than comparing what Britain produced relative to Italy, Ricardo compared what Britain could produce relative to itself. A country possessed a comparative advantage in the production of whatever it could produce most efficiently in the absence of any trade. Even a poor, inefficient, barren country with high prices could produce at least one good more efficiently than it produced any other good. Each country had a limited pool of productive resources-land, labor, and capital - which it could combine to produce a different mix of goods. The mix of resources contained in each country was most suitable to the production of a certain good. Ricardo showed with a simple mathematical proof that, if each country specialized in the production of the good in which it enjoyed a comparative advantage, some countries would gain, and none would lose, by then trading with each other at some intermediate price. This theorem is also known as the pure theory of trade.

The benefits of comparative advantage are known as the "static gains" from trade. These static gains include the one-time gains from lower costs to consumers who have access to less expensive foreign imports and one-time gains to producers from the increased production that results from a more efficient allocation of resources. The static gains from trade occur within the near term after barriers to trade are eliminated.

In addition to these near-term static gains are the longer-term "dynamic gains" from trade. Dynamic gains result from the increased competition from imports, and they continue over time. Import competition spurs domestic producers to lower prices and production costs. Lower prices means there are savings available for investment. Investment and competition accelerate innovation, which in turn, improves efficiency, increases productivity, and generates more wealth. In most cases, the dynamic gains from trade may be harder to quantify than static gains, but they are generally much greater and more 
significant than static gains.

The pure theory rests on the assumption that both importing and exporting countries have perfectly competitive markets. Only in perfect competition do the relative prices of goods reflect the actual cost of production of those goods. Only competitive market prices that reflect the true cost of production lead the market to determine a country's comparative advantage correctly. If the price does not reflect the cost of production, the market will misjudge the comparative advantage, and the resulting allocation of productive resources will be sub-optimal.

Four conditions are necessary for perfectly competitive markets. First, goods must be homogenous, or indistinguishable, so that buyers will decide which good to purchase based solely on price. Second, the market must include a sufficiently large number of buyers and sellers, so that no one party can control the price of a good. Third, there must be no barriers to entering the market, so that if sellers drive their competitors out of business and then raise prices, new sellers will be attracted to entering the market. Fourth, each buyer and seller must have sufficient knowledge of the market, so that every buyer will purchase goods from the lowest-priced seller, forcing all other sellers to match that price or drop out of the market. When there are many buyers and sellers with sufficient knowledge trading homogenous goods and no barriers to entering the market, we have perfect competition, forcing prices down to the point that the price of a good is almost equal to the cost of production.

\section{B. The Pure Theory in an Imperfect Market}

Neo-liberal economists readily acknowledge that there is a gap between the compelling logic of the comparative advantage and real market conditions. In actuality, most goods and services are not traded in perfect markets. The four requirements for a perfectly competitive market-homogeneous goods, a sufficiently large number of buyers and sellers, no barriers to entry, and perfect knowledge-rarely occur in international markets for the reasons that follow.

First, it is not true that all or even most goods traded in world markets are homogenous. Most processed consumer goods are protected by some form of intellectual property rights that prohibit others from reproducing and selling the identical good. At least for a period of years, most manufactured goods are protected by patents, and most artistic, written, or recorded materials are protected by copyrights. Virtually all manufactured or processed consumer goods are trademarked (indeed, even some primary products, like Evian water are trademarked). 
Producers advertise to persuade consumers that their branded product is distinguishable from any competing product, and consumers pay a premium for branded products over generic products. In other words, marketing is designed to undermine the homogeneity of goods. Advertising makes it possible for car manufacturers to sell vehicles that perform the same basic function with approximately the same basic features, size, and weight at widely divergent prices. Patents, trademarks, and copyrights together make most processed consumer goods and many producer goods non-homogenous. Industrialized countries, like the United States, almost exclusively export goods protected by patents, trademarks, and copyrights. ${ }^{13}$

Of course, many products protected by patents, trademarks, or copyrights, are readily substituted, and if prices among substitutable goods diverge too widely, some consumers will shift to a less expensive substitute. A consumer might be willing to pay a premium of 10,20 , or $30 \%$ for a product, but not $50 \%$. Still, if a brand name can command a premium of only $10 \%$, that may be enough to distort comparative advantage. For example, suppose that consumers are willing to pay $10 \%$ more for a pair of jeans with a Gap label over another pair of jeans with no label. That premium is more than triple the average rate of the tariff charged by industrialized countries of $3.0 \%$ on imports from other industrialized countries. ${ }^{14}$

The mere fact that goods are not homogenous might not necessarily distort competition. Even though intellectual property rights operate as a restraint on competition, they could be compatible with a competitive market if they are limited in scope, there are competitive substitutable goods, and there is an effective antitrust regime to prevent a producer from abusing their market power. Unfortunately, these three conditions often do not prevail in international markets.

First, there has been a general trend towards over-protection of patents and copyrights that has allowed producers excessive monopoly profits beyond what is necessary to encourage innovation.

Second, there often are no competitive substitutes for certain goods. Consider the large number of patented drugs or copyrighted software for

13. For example, U.S. exports of copyrighted goods alone, including books, periodicals, sound and film recordings, videos, and software, totaled $\$ 88.97$ billion in 2001. STEPHEN E. SIWEK, Copyright Industries in the U.S. Economy: The 2002 Report 24 (2002). The growth of information technology products and services has transformed U.S. trade since 1990. Export income to the United States from royalty and licensing fees grew an average of $8.3 \%$ annually from 1992 through 1999. COUNCIL OF ECONOMIC ADVISORS, ECONOMIC REPORT OF THE PRESIDENT, H.R. DOC. No. 107-2, at 155 (2001).

14. Kevin C. Kennedy, The GATT-WTO System at Fifty, 16 WIS. INT'L L.J. 421, 445 (1998). 
which there are no real substitutes. Even where substitutes exist, advertising by the largest multinational companies is so effective that consumers may not regard goods as substitutable, and they are willing to pay a premium for a trademark.

Finally, antitrust laws often are not effective in preventing the abuse of intellectual property rights. There has been a trend over the last thirty years towards less vigorous enforcement of antitrust laws in the industrialized countries in large part because of a belief that international competition was more relevant than competition within any specific national market. (Arguably, this trend may have begun to reverse itself with the rise of the post-Chicago school of economics in antitrust theory. ${ }^{15}$ ) Most developing countries and transitional market economies lack an effective antitrust regime for policing the market. These countries do not have the economic or legal expertise to investigate and prosecute anti-competitive behavior. As a result, goods that are protected by patents, trademarks, and copyrights often are not traded in competitive markets.

Even as to goods that are unprocessed or not sold directly to consumers, like raw minerals, unprocessed agricultural products, fish, or timber, there may be real or apparent differences that undermine homogeneity. Not all raw minerals or agricultural products are the same worldwide. Some consumers will pay a premium for Saudi crude oil, Brazilian coffee beans, Norwegian salmon, or Canadian hardwoods. Certain distributors, such as Chiquita, advertise that their brand label assures consumers of inherent quality that demands a premium. These distributors are often large enough to control market prices.

Second, the number of buyers and sellers is often insufficient for a perfectly competitive market. A large percentage of goods are traded in markets with few players. Many developing, socialist, or transitional economies centralize control of imports and exports through state trading enterprises. Large multinational corporations frequently exercise market dominance. Multinationals are especially dominant in developing countries and may control access to foreign markets. In Japan and Europe, weak enforcement of competition laws have allowed giant conglomerates and networks of inter-related companies, like the Japanese keiretsu, to dominate several different and related markets. Within a Japanese keiretsu, for example, companies generally are expected to make all their purchases from affiliates regardless of pricing.

15. Ashutosh Bhagwat, Unnatural Competition?: Applying the New Antitrust Learning to Foster Competition in the Local Exchange, 50 HASTINGS L.J. 1479, 1487-93 (1999). 
In addition, a large portion of world trade occurs within a multinational. In the United States, for example, about $37 \%$ of merchandise exports and $48 \%$ of merchandise imports are traded intrafirm. ${ }^{16}$ When General Electric, for example, imports parts from a subsidiary in Hungary for production in the United States and re-exports to another affiliate in Latin America, the company's management determines the pattern of trade. Perhaps General Electric could purchase the same part more cheaply from an unrelated company in Taiwan, but General Electric has made an investment in its own subsidiary, which is competing with the Taiwan firm. There are executive officers whose careers within the company depend upon the success of the subsidiary. Moreover, the actual cost of the part to the company may be difficult to determine. The price that the subsidiary charges to the parent company is an artificial transfer price that does not necessarily reflect the actual cost of the product. Multinational companies routinely use transfer pricing to shift income among affiliates to minimize taxes and avoid foreign exchange controls.

Third, there are often significant barriers to entering the international market, which distort market pricing. However much GATT has reduced tariff barriers to trade, non-tariff barriers persist. Many countries have state trading enterprises or foreign exchange controls that limit who can import or export. Taxes, subsidies, customs regulations and inspections, technical barriers to trade, health and safety requirements, import and export licensing, quotas, and government procurement policies all limit access to foreign markets.

Fourth, the requirement that buyers and sellers have perfect knowledge of market pricing is rare given the sheer size and complexity of the world market. A consumer seeking to purchase an automobile has only imperfect information about who is willing to sell what car at what price. If a consumer does not know the price of a Ford Taurus among all the available Ford dealers in her vicinity, she certainly cannot compare the prices of all Fords produced in the United States with the prices of all comparable imported cars. In some markets the knowledge gap may be filled by brokers or by large institutional players who engage in hedging. For example, the World Wide Web has made more price information available to consumers. Still, for most of us, more information does not necessarily mean greater knowledge; a flood of market information often overwhelms our ability to process it. Consumers armed with information from the World Wide Web may be

16. Stephen D. Cohen et Al., Fundamentals of U.S. Foreign Trade Policy 71 (1996). 
no more knowledgeable, just more confused, than consumers purchasing blindly in the market. For these reasons, the four conditions necessary for a perfectly competitive market are generally not satisfied by the international market.

As stated above, comparative advantage only works if price signals work properly. In addition to imperfect competition, prices of goods and services in international trade often do not reflect the actual costs of production for a variety of other reasons. Foreign exchange rates are one major problem with the pricing of imports and exports. In principle, exchange rates reflect the demand for a country's goods and services. If there is a high demand for exports, the value of a country's currency should rise; if there is a low demand, the currency's value should fall. That has not worked in practice, however, because of the influence of financial transactions on exchange rates. The United States has had a large and persistent current account deficit for more than 20 years, yet the U.S. dollar has remained strong. As of September 2003, the projected U.S. annualized merchandise trade deficit exceeded $\$ 500$ billion, and yet the dollar has appreciated against our trading partners during the last several years. ${ }^{17}$ The strong dollar has made it cheaper for Americans to buy foreign imports and travel abroad, while it has priced U.S. exports out of foreign markets. The apparent reason for the continued strength of the dollar is the attractiveness of the U.S. dollar itself as a medium of exchange and investment. As a result of distorted exchange rates, U.S. exports may look expensive, while Japanese exports may look inexpensive, even for products in which the United States enjoys a comparative advantage. ${ }^{18}$

Ricardo was describing a world in which exports and imports consisted primarily of tangible goods. In 2000 , about $23 \%$ of the world's trade consisted of services, which included professional services, financial services, licensing and royalty fees, tourism, education, transportation, and communication that crossed borders. In the United States about $35 \%$ of our exports consisted of services in $2000 .{ }^{19}$ Some services, especially financial services, may be traded in

17. As reported in "U.S. Deficit Widens in July as Demand for Consumer Goods Becomes Stronger," 20 Int'l Trade Rep. (BNA) 37, at 1540 (Sept. 18 2003). The real effective exchange rate for the U.S. dollar has generally increased since 1992 as the current account deficit rose. See COUNCIL OF ECONOMIC ADVISORS, ECONOMIC REPORT OF THE PRESIDENT, supra note 13, at 159 , Chart 4-4.

18. Id. at 58-60 (1996).

19 Based upon WTO statistical analysis. Press Release, World Trade Organization, World Trade Slows Sharply in 2001 Amid the Uncertain International Situation (Oct. 19, 2001), at $\mathrm{http} / / / w w w . w t o . o r g / e n g l i s h / n e w s \_e / p r 249 \_$e.htm. It is very difficult to measure services because 
competitive markets, but most services are non-homogenous and highly regulated. A U.S. lawyer cannot perform the same function in Brazil as a Brazilian attorney; tourism in Florida is not directly competitive with tourism in Norway; banks, insurance companies, airlines, shipping lines, truckers, television, radio, and telephone are regulated in ways that often create preferences for domestic service providers and disadvantage or bar foreign service providers from the domestic market. The TRIPS Agreement liberalizes the regulation of service providers to some extent, but it remains true that the vast majority of services are not traded in a competitive market, and the pure theory is inapplicable to this portion of world trade.

Moreover, capital flows are substantially greater than the total volume of visible trade in goods and invisible trade in services. ${ }^{20}$ The ease with which capital can be moved from one jurisdiction to another is a marked difference from the era in which Ricardo lived. Labor today is relatively immobile compared to capital, and indeed, it may be less mobile than it was in Ricardo's day, because of the increased regulation of immigration, which was fairly relaxed in the early part of the nineteenth century. As a result, capital can vote with its feet, moving to jurisdictions with lower labor costs and less burdensome economic or environmental regulation. That creates the opportunity for regulatory competition to force down regulatory standards. ${ }^{21}$

Perfect markets, or nearly perfect markets, may exist for some products in some markets at least some of the time. For example, the worldwide markets for financial assets, foreign exchange, and most raw minerals may be nearly perfect markets. However, the assumption of a perfect market, which is necessary for comparative advantage to work,

they are not subject to customs valuation, services are traded intra-firm and through telecommunications that defy government accounting, and services like tourism and education are largely measured based upon surveys of foreign visitors that are notoriously inaccurate. Therefore, any measurement of services is highly approximated. Most economists believe that the actual import and export of services may be much greater than the official account.

20. There are several ways to compare the size of world trade and capital markets, but the clearest method is to compare the value of world exports and the value of foreign currency exchanges. The total value of world exports in goods and services in 1997 was \$6.6 trillion. International financial markets exchange $\$ 1.5$ trillion in foreign currency each day. To put it succinctly, foreign currency transactions alone are 60 times greater than world trade in goods and services. COUNCIL OF ECONOMIC ADVISORS, ECONOMIC REPORT OF THE PRESIDENT 224 (1999).

21. See John Douglas Wilson, Capital Mobility and Environmental Standards: Is There a Theoretical Basis for a Race to the Bottom?, in JAGDISH BHAGWAT \& ROBERT HUDEC, 1 FAIR TRADE AND HARMONIZATION 393 (1996). Under certain rare circumstances, regulatory competition may lead to an improvement in regulatory standards. See Joel R. Paul, Free Trade, Regulatory Competition, and the Autonomous Market Fallacy, 1 COLUM. J. EUR. L. 29, 57-58 (1995). 
is not operative for the vast majority of goods and services in world trade. With confession and avoidance, proponents of international trade institutions readily acknowledge that the international markets are imperfect, and the pure theory may not work in imperfect markets. Yet, these same proponents deny the reality of how markets perform in their zeal for free trade.

\section{Empirical Measurements of the Gains from Trade and Sunk Costs}

What percentage of the world's exports is actually traded under perfect market conditions free from market failures and distortions? To measure the actual scope for comparative advantage we would need to exclude most consumer goods protected by trademarks, patents, copyright or trade secrets; all subsidized products, including most agriculture produced in industrialized countries; most government procurement; goods subject to tariffs, duties, subsidies, or quotas; products traded within preferential regional trading blocs or subject to other free trade agreements, historical preferences, or special arrangements (like the Caribbean Basin Initiative, the British Commonwealth, or the Free-Trade Agreement with Israel); goods controlled by international cartels, monopolies, producer associations, or commodity agreements; products bought or sold by state trading companies; many goods subject to technical requirements; environmental, health, or labor regulations that create preferences; and goods traded within multinational enterprises. Though a precise calculation is difficult, my best estimate is that the real size of the competitive market in which comparative advantage operates effectively is not greater than $25 \%$ of the world's exports and probably significantly less.

The narrow scope in which comparative advantage actually operates may explain why the gains from trade are so small. When economists have tried to measure the gains from trade they have found that the static gains-the gains predicted by the pure theory-are usually in the range of 0.1 to $0.5 \%$ of gross domestic product (GDP). ${ }^{22}$ Gains to GDP

22. For example, according to the President's Council of Economic Advisers, NAFTA has yielded an increase in the gross domestic product of $0.1-0.5 \%$., and when fully implemented the Uruguay Round could add as much as $\$ 27-37$ billion annually to the gross domestic product, which is about $0.4-0.6 \%$ growth (estimates in 1992 dollars). COUNCIL OF ECONOMIC ADVISERS, supra note 6; COUNCIL OF ECONOMIC ADVISERS, AMERICA'S INTEREST IN THE WORLD TRADE ORGANIZATION: AN ECONOMIC ASSESSMENT (Nov. 16, 1999), available at http://clinton4nara.gov/media/pdf/WTO-Final.pdf. These figures are consistent with other studies of the gains from trade. For example, when the European Community established the Single 
of this magnitude are within the normal range of error in estimating or may be due to other factors such as fluctuations in interest rates, increases in fiscal spending, or weather conditions. ${ }^{23}$

Another way to measure the gains from trade is to consider the effects of trade on employment. Gains to employment from trade agreements are hard to quantify. Economists disagree about how an increase in imports affects job losses and how an increase in exports affects job gains. For example, the U.S. Trade Representative claimed in 2001 that U.S. jobs supported by merchandise exports under NAFTA increased from $1993-2000$ by roughly $900,000{ }^{24}$ This study, however, relied on the questionable assumption that there is a fixed numerical relationship between the number of jobs and the value of exports and did not fully take into consideration the impact on import-competing industries. Studies from outside the government, in contrast, dispute these figures based upon the actual changes in employment in certain industries and claims filed for trade-adjustment assistance. One such study found that there was a loss of 1.9 million jobs in manufacturing alone from 1994-2000 as a result of the increase in imports from NAFTA and the WTO. ${ }^{25}$ Some other studies suggest that workers in export-related jobs earn more than workers who do not produce exports, but these studies do not consider the effect on income as high-priced union jobs in the import-competing manufacturing sector are replaced by lower priced non-union domestic service-sector jobs. From 1980 to 1995 as trade increased, real wages for employees in all but the highestincome quintile fell. Due to the loss of jobs from imports on a riskadjusted basis, even the value of the wages of the highest-income quintile decreased. ${ }^{26} \mathrm{~A}$ study by the Institute for International

Market in 1986, the Ceccini Report of the European Commission estimated that it would result in a net gain of $1-3 \%$ of the gross domestic product of the European Union over a period of five years.

23. Earlier estimates of the gains from trade are consistent with these studies. For example, in 1958, Harry Johnson estimated the gains from free trade forecasted for 1970 would be about $1 \%$ of GNP. Harry G. Johnson, The Gains from Freer Trade with Europe: An Estimate, in 26 MANCHESTER SCHOOL OF ECONOMIC AND SOCIAL STUDIES 247, 255 (H.G. Johnson, ed., 1958).

24. To put this number is perspective, during the same period the U.S. economy as a whole generated 12.8 million new jobs. In other words, even in the absence of NAFTA there would have been an increase of nearly 12 million jobs. USTR Documents Benefits of Trade for American Families, Press Release dated September 19, 2001, available at www.ustr.gov.

25. Robert E. Scott, Fast track to lost jobs: Trade deficits and manufacturing decline are the legacies of NAFTA and the WTO (Oct. 2001), available at http://archive.epinet.org. The study found that although U.S. exports increased $61.5 \%$ or $\$ 359$ billion creating 2.8 million jobs during this period, U.S. imports rose by $80.5 \%$ or $\$ 616$ billion eliminating 5.8 million jobs. Id. at 4 .

26. Jeffrey N. Gordon, Employees, Pensions, and the New Economic Order, 97 CoLUM. L. REV. 1519, 1525-26, 1534-38 (1997). U.S. real wages declined for most of the period from 1969 
Economics (IIE), perhaps the most authoritative recent study, concluded that despite the worst fears of NAFTA's critics and the inflated promises of NAFTA's supporters, there was no measurable net gain or loss of U.S. employment. ${ }^{27}$ In short, there is no definite empirical evidence of large static gains from trade.

When comparative advantage works, it necessarily means that some industries prosper while others die. In a free market, "creative destruction" through competition ensures that productive resources shift to their highest and best use. Not all resources, however, are moveable. You cannot turn an automotive factory into a dairy farm; a 50-year-old factory worker probably will not make a good computer engineer; and a factory town in Maine cannot grow oranges. Each of these resources may be lost in the shift from an import-competing business to an exportcompeting business, and that loss represents "sunk costs." Sunk costs have adverse economic consequences. If factory equipment is unusable, investors lose financial capital. If workers cannot be retrained to support themselves or their families, human capital is lost. If towns lose their economic base, land loses value, and other businesses that provide goods and services to the unemployed workers and failed industries will also be hurt. In addition to these sunk costs, unemployed resources also increase social costs. Unemployed workers require public support and pay less in taxes, reducing government revenues. Unemployed workers develop more health problems and family issues, such as substance abuse and domestic violence. Communities with large numbers of unemployed workers also have higher rates of crime and juvenile delinquency, which add to the social cost.

It would be difficult to measure all of the sunk costs and social costs that result when import-competing businesses are displaced. We know that sunk costs and social costs are not insignificant. We also know that the static gains from trade are very modest. Balancing the costs and

through the mid-1990s. The latter half of the 1990's saw some increase in the average real wage due to technological changes. "Most economists agree that technological change explains about half of the rising US skill premium while trade and immigration forces account for around 10 and 5 percent respectively." Gary Clyde Hufbauer \& Jeffrey J. Schott, North American Labor Under NAFTA 9 (Sept. 2002), available at http://www.iie.com/publications/papers.nafta-labor.pdf.

27. As of December 2001 the Department of Labor had certified that some 370,000 U.S. workers had been displaced by imports and were eligible for trade adjustment assistance. This number tends to underestimate the actual number of displaced workers, since only a fraction of displaced workers apply for assistance. One study concluded that NAFTA alone had eliminated 766,030 jobs between 1994 and 2000. Another study claimed that NAFA had created 709,988 jobs, about 140,000 jobs annually. It is probably impossible to accurately measure the net job growth or job loss when the number of affected workers is so small relative to the total number of jobs in the U.S. economy. Hufbauer \& Schott, supra note 26, at 5, 7-8. 
benefits from trade, we cannot say a priori that the gains from trade are enough to offset the costs in the near term.

Proponents of trade respond that even if the costs exceed the gains from trade in the near term, the dynamic gains from trade over the long term are likely to produce a net benefit. Dynamic gains from trade derive from the increased import competition, which forces competitors to cut costs and raise productivity through innovation. Trade encourages specialization. By specializing in the production of a good in which a country has a comparative advantage, firms can achieve greater economies of scale, which lowers their marginal cost of production. When consumers pay lower prices and industry has lower costs, both increase savings. Increased savings provides new investment for industry, which allows firms to improve technology and expand production.

Dynamic gains over the long term, however, are more speculative than the static gains in the near term. Dynamic gains are diffused over time. They depend upon competitive conditions in the market. If governments do not have competition policies to police the market, then increased trade may drive out local industry and reduce market competition. Without competition, the dynamic gains from trade are lost. Even where dynamic gains occur from increased competition, they do not benefit all countries equally. Cost savings may generate increased investment, but the cost savings in one country may be reinvested in another country. Economies of scale can be achieved through specialization without engaging in free trade. For all these reasons, we cannot defend the WTO as an engine of economic growth based on any measurable gains from trade.

\section{Social Welfare Gains and Losses from Trade}

The pure theory acknowledges that trade will yield winners and losers. Some industries will prosper from exporting, and consumers will enjoy lower prices from import competition. Import competition will also displace some industries, and some workers will lose their livelihoods, and investors will lose the value of their investment. The pure theory tells us that when resources are efficiently allocated the winners will gain more than the losers lose. Therefore, the winners could compensate the losers for their losses, and everyone could be better off.

In the real world, winners do not generally compensate the losers for their losses. Winners get rich, and losers become poor. Although the pure theory tells us that trade will maximize the world's aggregate 
output, it does not necessarily maximize social welfare, in the sense of a society's aggregate sense of well-being.

Economists describe social welfare in terms of "utility." The concept of utility represents the extent to which an individual experiences satisfaction or happiness from a change in income. We expect that as an individual's wealth rises, so does their total utility. For every additional unit of income that an individual gains, there is some additional quantity of utility. The amount of utility that an individual gains from each additional unit of income is an individual's "marginal utility." If an individual loses a unit of income, marginal utility represents the amount of utility lost. ${ }^{28}$

Every person's marginal utility varies, and each individual's marginal utility changes as her income rises or falls. As a result, if two individuals receive $\$ 100$, they will not necessarily experience the same increase in marginal utility. A wealthy person who does not need any more money will generally value the additional $\$ 100$ less than a poor person, for whom $\$ 100$ may represent an enormous sum. In general, the more wealth a person has, the less satisfaction (marginal utility) she will gain from each additional dollar she earns. Conversely, the more income a person loses, the more unhappiness (marginal utility lost) she will suffer from each additional dollar lost. From this simple observation of human nature, we can assume that affluent people tend to have lower marginal utility than poor people. If a worker loses $\$ 100$ on the street, and a rich industrialist finds the money, we would expect that the loss of utility to the worker would be more than the gain of utility to the wealthy industrialist. Though the aggregate income of these two persons has not changed, their aggregate social welfare has declined.

To determine if marginal losses outweigh marginal gains from trade, we need to consider who benefits and who suffers by increased trade. If low-skilled workers surviving on modest incomes lose their livelihoods, while more affluent, highly-skilled workers and consumers benefit from increased trade, the marginal utility losses of low-skilled labor may exceed the marginal utility gains of more affluent workers and consumers. In this manner, trade may increase aggregate world output, but social welfare may fall.

In the United States, for example, import competition has forced some manufacturing plants to go out of business or move to lower-wage countries. Many industries have relocated their manufacturing from industrialized countries with high-wage union labor to developing

28. For a critique of standard marginal utility analysis, see Walter Blum \& Harvey Kalven, The Uneasy Case for Progressive Taxation, 19 U. CHI. L. REV. 417 (1952). 
countries with low-wage non-union labor. Job losses in manufacturing have been concentrated in textiles, electronics, chemicals, steel, and automotive parts, all industries in which there are high degrees of unionization and relatively good wages. ${ }^{29}$ While some displaced workers find other high-paying jobs in the export sector, more find lower-paying jobs in the services sector. ${ }^{30}$ This phenomenon has held down real median wages in the United States for most of the period since $1980 .^{31}$

In principle, highly-skilled workers and industries that have benefited from access to foreign markets, could compensate the less-skilled workers and industries for their losses. ${ }^{32}$ The political reality in the United States makes it unlikely that winners will be taxed to compensate losers. ${ }^{33}$ As globalization increases there has been a pronounced shift in U.S. politics away from progressive taxation and redistributive social welfare programs. ${ }^{34}$ The political forces that oppose redistribution are generally the same interests that support the WTO, NAFTA, and the FTAA. That is not a coincidence. The "Washington Consensus" that favors open trade and deregulation also favors market

29 Scott, supra note 25 , at 6-8. The percentage of unionized workers has fallen from $35 \%$ in 1950 s to $13.5 \%$ in 2000 , and disproportionately those workers are employed in the public sector. See Hufbauer \& Schott, supra note 26 , at $15-16$. Among private sector workers, only $9 \%$ are unionized. The contraction of unionization has held down wages over the last 25 years.

30. In general, workers who lose their jobs earn less when they are reemployed. One study of displaced workers in the 1970 s and 1980 s showed that the average wage declines $29 \%$ in the year after losing a job. COUNCIL OF ECONOMIC ADVISERS, ECONOMIC REPORT OF THE PRESIDENT, supra note 13 , at 123 . Another study in 2001 showed that only $36 \%$ of workers who are displaced by imports find jobs that pay equal or higher wages, and about $20 \%$ of displaced workers have wage losses in excess of $30 \%$. Hufbauer \& Schott, supra note 26, at 10.

31. Median real hourly wages from 1979 through 1993 were essentially unchanged, while median real wages for men fell by $11.1 \%$. From 1994 through 2000 , median real hourly wages rose slightly, pushed up by a $1.9 \%$ increase in 1997 in median real wages for women. COUNCIL OF ECONOMIC ADVISERS, ECONOMIC REPORT OF THE PRESIDENT, supra note 13, at 101-02.

32. In fact, the Federal Government provides some limited assistance in the form of Trade Adjustment Assistance (TAA) to help workers who lose their jobs as a result of increased imports to find new jobs. See COUNCIL OF ECONOMIC ADVISERS, supra note 6, at 9. TAA does not actually compensate workers displaced by imports, and the program is generally regarded as too little too late.

33. The growth in GDP has not been shared equally. The share of real aggregate income received by the top fifth of households rose from $16.6 \%$ in 1969 to $22.4 \%$ in 2001 . The share received by the bottom fifth fell from $4.1 \%$ to $3.5 \%$, and the share received by the middle fifth also fell from $17.5 \%$ to $14.6 \%$. U.S. CENSUS BUREAU, INCOME IN THE UNITED STATES 25, Table A-3 (September 2003), available at http://www.census.gov/prod/2003pubs/p60-221.pdf.

34. For example, in 2003 the Bush Administration is negotiating the FTAA to increase trade. At the same time, the President is proposing cuts in social programs (including TAA), opposing any extension on unemployment benefits, and pushing to eliminate the tax on corporate dividends, which would principally benefit the wealthiest $1 \%$ of taxpayers. The President has never proposed that the winners who gain the most from trade should compensate the losers. 
incentives and opposes social welfare programs. Thus, the argument by WTO proponents that the winners could compensate the losers from trade is disingenuous. They "could," but the same proponents generally argue that they "should not."

Gross domestic product per capita has risen in the United States over the last three decades partly as a result of increased trade, but more output does not mean that the people of the United States in the aggregate feel happier from the increased income. We cannot know a priori whether the increased satisfaction of millions of consumers who are able to buy more goods at lower prices is necessarily greater than the loss of satisfaction from hundreds of thousands of workers who have - lost income. The aggregate loss of utility to society may be greater than the aggregate gain of utility. In this way society as a whole may experience a net reduction in social utility as a consequence of trade..$^{35}$

35. In the United States the social consequences of this rising inequality are aggravated by race. The underclass of lower-skilled, less-educated workers displaced by imports are disproportionately African-American and Latinos. The manufacturing sector has both the highest proportion of minorities and also the highest proportion of job losses over the last 20 years due to import substitution. U.S. Trade Deficits: Causes, Consequences and Policy Implications: Hearing Before the S. Finance Comm., 105th Cong. 97-98 (1998) (statement of Robert E. Scott, Economist, Economic Policy Institute). The greatest job losses were concentrated in those manufacturing industries with the highest numbers of minorities. Electronics and apparel account for $51 \%$ of all manufacturing plant closures in the United States, and these sectors employ roughly twice the average proportion of minority workers. Canadian Labour Congress, Impacts of NAFTA on US Workers: U.S. Labour Market Trends, at http://www. clcctc.ca/policy/trade/nafta3.html (last visited Oct. 7, 2003). One study reported that out of a total of 3.6 million displaced manufacturing workers, about 700,000 were African-American or Latino. More than $50 \%$ of the African-Americans lost jobs because plants closed to relocate outside of the country. Clarence Lusane, Persisting Disparities: Globalization and the Economic Status of African Americans, 42 HOWARD L.J. 431, $441-42$ (1999).

As a result, African-American and Latino workers have generally experienced a loss of real income during the last two decades of increased trade. The bottom decile of workers is disproportionately black and Latino. From 1979 to 1993 the real hourly wages of these workers fell by more than $15 \%$. COUNCIL OF ECONOMIC ADVISERS, ECONOMIC REPORT OF THE PRESIDENT, supra note 20, at 107-09. Median hourly wages of all African-Americans and Latinos have stubbornly remained about $70-73 \%$ of median hourly wages for whites since 1979 . The wage differential has meant that minority household incomes have not kept pace with the household income of whites. The median household income for whites rose from $\$ 36,805$ in 1969 to $\$ 45,860$ in 2000 . During the same period, the median household income of blacks rose from $\$ 22,247$ to $\$ 30,980$. U.S. CENSUS BUREAU, INCOME IN THE UNITED STATES: 2002 , at 17-19, Table A-1. Unemployment rates among African-Americans and Latinos have also remained about twice that of whites. COUNCIL OF ECONOMIC ADVISERS, ECONOMIC REPORT OF THE PRESIDENT, supra note 20, at 107-09. Due to lower wages and higher unemployment, blacks and Latinos have had poverty rates two- or three-times that of whites during the last decade. In 2001 , the poverty rate for non-Hispanic whites was $7.8 \%$, while the poverty rate for African-Americans was nearly three-times that, $22.7 \%$. U.S. CENSUS BUREAU, POVERTY IN THE UNITED STATES: 2002 CURRENT POPULATION REPORTS 2 (September 2003), available at http://www.census.gov/prod/2003pubs/p60-222.pdf. 


\section{E. Constructed Comparative Advantage}

Ricardo imagined a world in which comparative advantage was predetermined and immutable. Countries had particular climates and resources that predetermined their comparative advantage. A country with a temperate climate, plenty of open land, and rich fertile soil might possess a fixed comparative advantage in agriculture; while a country with a cold climate and high population density would presumably enjoy a fixed comparative advantage in manufacturing. So long as comparative advantage is seen as natural and immutable, anything the government does to influence or interfere in the market will distort the natural comparative advantage and reduce social welfare. This assumption about a natural and immutable comparative advantage has proven false.

The economists Heckscher and Ohlin theorized that a country's comparative advantage would be determined by the relative abundance of resources. ${ }^{36}$ In conditions of free trade, a country that had an abundance of capital would export capital-intensive goods, whereas a country with an abundance of labor would export labor-intensive goods. In 1954, the Nobel economist, Wassily Leontief, tested HecksherOhlin's theorem and found that the United States, a capital-rich country, actually exported labor-intensive goods, contrary to the theorem. This observation, known as Leontief's Paradox, seemed to call into question whether comparative advantage is actually determining the pattern of trade. ${ }^{37}$

Several explanations have been offered for Leontief's Paradox. The most cogent explanation is that one cannot know a priori whether a good is labor-intensive or capital-intensive. Different countries deploy labor and capital in different ways, depending on technology. China may produce rice using large amounts of labor, while the United States produces rice using large amounts of expensive machinery and chemicals. Rice is a labor-intensive good in China, but a capitalintensive good in the United States. Contrary to the assumption that a country's advantage in trade is natural and immutable, Leontief's

36. For a succinct explanation of the Heckscher-Ohlin theory, see 2 THE NEW PALGRAVE: A DICTIONARY OF ECONOMICS 620-26 (John Eatwell eds., 1987). See generally, BERTIL OHLIN, INTERREGIONAL AND INTERNATIONAL TRADE (1933); Paul A. Samuelson, Prices of Factors and Goods in General Equilibrium, 21 REV. ECON. STUD. 1 (1953-54).

37. For a succinct explanation of Leontief's Paradox, see 3 THE NEW PalgRave: A DICTIONARY OF ECONOMICS 166-67, (John Eatwell et al. eds., 1987). See generally, Wassily Leontief, Domestic production and foreign trade: the American capital position re-examined, reprinted in AMERICAN ECONOMIC ASSOCIATION, READINGS IN INTERNATIONAL ECONOMICS 503-27 (H.G. Johnson \& R.E. Caves eds., 1968). 
Paradox demonstrates that comparative advantage may be shaped by forces like technology, culture, or government policy. ${ }^{38}$

Government policy determines comparative advantage in a variety of ways. Technology itself is often the product of government policy. Governments provide public education, research funds, and tax incentives to promote technology. Government agencies contract for technology. Military contracts, for example, provide substantial subsidies for the development of technology. In this way, government policy creates the technology that determines comparative advantage. The United States has dominated the world aerospace market in large part because government contracts have provided billions of dollars in subsidies to the aerospace industry. U.S. government support for railroads and highways opened up the farms of the mid-west to world markets and created a comparative advantage in wheat, soya, and chickens, among other exports. The Dutch flower industry, the Korean steel industry, the Norwegian fishing industry, and the Canadian timber industry have all succeeded in world markets in large part due to government policies.

In fact, almost everything that we assume is an essential governmental function (taxing; building highways; protecting the public's security; promoting consumer and worker safety; providing clean water and electricity; educating children; enforcing contracts; policing fraud; and regulating financial markets, competition, and corporate governance) influences a country's comparative advantage. It is unthinkable that a government could simply withdraw from the myriad activities that facilitate markets and construct comparative advantage in this way. As discussed below, the WTO regime does not require a government to withdraw from all of these functions, but rather prescribes what kinds of government functions and aid to industries are acceptable. These judgments represent policy choices, not an imperative of free markets.

Government policy may also disadvantage certain industries. The minimum-wage laws, social security, and the occupational-safety

38. Leontief's Paradox is also illustrated by the widely observed phenomenon of cross-trade. Contrary to the pure theory of trade, most countries import and export at least some of the same products. WTO, INTERNATIONAL TRADE STATISTICS 2002 (2002), available at http://www.wto.org/english/res_e/statis_e/its2002_e/its2002_e.pdf. The United States, for example, imports and exports steel, automobiles, chemicals, tools, fruits, wine, and airplanes. At least part of the reason for cross-trade is that countries use different technologies to produce these goods and the same good produced in different countries is not necessarily fungible. California wine, for example, has qualities that distinguish it from French, German, or Australian wine. See, e.g., id. at 129-30, 143-44. 
regulations raise the cost of labor. That burdens some industries that must compete with imports produced by low-wage workers, and thereby confers an advantage on competing imports. In this sense, industrialized countries' labor laws construct an advantage for some labor-intensive industries in developing countries with lower labor standards.

Comparative advantage is often dictated by the necessary and selective operations of government. Government policies advantage some, and disadvantage other industries. The pure theory does not support the conclusion that reducing the role of government in the market and liberalizing regulation will necessarily produce greater wealth. As discussed below in Part Three, the GATT permits some forms of government intervention and prohibits others. In some circumstances, GATT prohibits government subsidies that would promote wealth; in other circumstances, GATT allows subsidies that distort efficiency. If comparative advantage is constructed (not natural or immutable), then the question whether a state is distorting comparative advantage or creating it by promoting certain industries is indeterminate.

\section{F. Summary}

The justification for expanding trade through international trade institutions, like the WTO, the NAFTA, and the FTAA, is that these institutions promote economic growth and development. In fact, there is no theoretical basis or empirical evidence to support this argument. Trade theory assumes a perfect market, which exists only for a few commodities. Without a perfect market, free trade does not necessarily allocate productive resources efficiently. The empirical measurements of the static gain from trade are consistent with this view that efficiency is not achieved. The sunk costs and social costs from trade are likely to be greater than the marginal gains, at least in the near term. Dynamic gains from trade are more speculative and depend on competitive conditions in the market. Even to the extent that there are gains from free trade, social welfare is not necessarily improved when the benefits and costs of trade are not shared by all members of society. Finally, comparative advantage is often created by government, rather than revealed by the invisible hand of the market.

Even if trade does not maximize world wealth, it may contribute to economic activity, especially in the poorest regions of the globe. Proponents of international trade institutions often argue that the benefits of trade are shared by rich and poor alike, and that trade reduces global income inequality. Some would argue that developing 
countries have the most to gain from liberalized trade. Part Two considers whether international trade promotes a more equitable distribution of the world's wealth.

\section{Distributional Consequences of InTERnational Trade}

Proponents of the WTO routinely claim that the WTO contributes to raising everyone's living standards by reducing trade barriers. They argue that the discipline of open trade imposed by international trade institutions should lead to decreasing income inequality as the world's poorest nations catch up to the industrialized countries. Of course, the pure theory of trade does not promise that the benefits from trade will be shared equally. In fact, there is substantial evidence that the growth of international trade has increased global income inequality.

Before getting to the question of whether trade causes income inequality, we must first determine if income inequality is growing. Studies of global income inequality yield differing results depending upon how inequality is measured. Economists face three methodological issues that may determine whether inequality appears to increase or decrease with trade: First, economists must decide what is the appropriate subject for analysis. Economists could look at the income distribution within each country separately (intra-country income distribution); or they could compare GDP per capita of different countries as if each country was equal to every other (unweighted intercountry income distribution); or they could weight the GDP per capita by population (population-weighted inter-country income distribution); or economists could ignore national boundaries and look at the income distribution among all individuals in the world (world income distribution). Each of these approaches has some advantages and methodological biases. ${ }^{39}$

39. There are sound arguments for focusing the economic analysis on each of these subjects. The most accurate economic data is available by country, which is a good reason to focus on intra-country income distribution. However, intra-country analysis does not tell us what is happening on a global level, unless we compare different countries. If inequality has increased in China and decreased in Israel, we cannot compare them fairly without taking population into consideration. That argument favors employing inter-country analysis. However, if we weigh countries by population, then a few large countries tend to skew the results for all countries. In principle, a better measure of income inequality is probably world income distribution, which compares all individuals in the world without regard for their nationality. World income distribution is difficult to measure and is also biased by the changes in income in a few large countries. Intra-country income inequality has increased dramatically in China and India, which represent about $35 \%$ of the world's population. Yet, because they are so large, an increase in their median income may make it appear that income inequality on a global level is decreasing. Xavier 
Second, economists must decide how to measure inequality. Economists have developed a number of tools for this purpose. The most straightforward method of analysis is to compare the top and the bottom ten (decile) or twenty percent (quintile) income levels. Comparing deciles or quintiles indicates how trade affects the richest and the poorest members of society, but it does not indicate how the middle-class is affected. Alternatively, economists construct coefficients that sample the distribution of income along the income range. ${ }^{40}$ Coefficients do a better job of measuring the middle-income range, but understate the impact of trade on the poor.

A third methodological issue is how to value income earned in different countries. The simple approach is to convert local currencies into dollars at the international exchange rate. Exchange rates tell us how much a person in one country could buy in foreign markets, but it does not measure how much he could purchase in his own country. To compare income purchasing power in one country with another, economists ask how much would the same basket of goods cost in different countries. That measurement is represented by "purchasing power parity" (PPP). In principle, PPP provides a better measure of the quality of life in different countries, since prices for some locally produced goods and services in developing countries may be much lower than in industrialized countries. However, PPP raises other difficulties. To determine PPP, economists need to collect a large amount of data about average prices of many items in many countries over a period of years, and this data is often unavailable or inaccurate. PPP also tends to understate the income gap between industrialized and developing countries, because people in developing countries consume more cheap services and fewer expensive imports than people in industrialized countries. ${ }^{41}$ For example, a middle-class Indian may rely

Sali-i-Martin, The Disturbing 'Rise' of Global Income Inequality, 2002 COLUM. U. DEP'T ECON. DISCUSSION PAPER SERIES \#:0102-44, 29-30. Some economists favor excluding China and India from the analysis of world income distribution. If we want to study the effect of trade on the income of individuals, as opposed to states, then the best approach would be world income distribution, but world income distribution also requires the most data and is therefore more difficult to measure accurately than intra-country or inter-country income distribution.

40. The most common index is the Gini coefficient, which indicates how income is distributed between perfect equality, represented by zero, and absolute inequality, represented by 1. A rising Gini coefficient indicates that inequality is increasing. The Gini coefficient tends to be a less accurate measurement than the comparison of income deciles or quintiles because it does not give as much weight to changes at either end of the income range as it gives to changes in the median income. Robert Hunter Wade, Is Globalization Making World Income Distribution More Equal?, 2001 LSE DEV. STUD. INST. WORKING PAPER SERIES NO. 01-01, 6.

41. Id. at 9. Wade argues that exchange rates are more useful for determining the effect that the industrialized world has on developing countries' economies and their ability to repay foreign 
on several household servants to perform the same functions for which a middle-class American uses a washing machine and an automobile. Household servants are much more costly in the United States than in India, but that does not mean the middle-class Indian is better off than the middle-class American.

Depending upon the unit of analysis, the form of measurement, and the valuation employed, economists have disagreed as to whether global inequality is rising or falling. ${ }^{42}$ A comparison of eight studies by leading economists using alternative combinations of approaches indicated by a preponderance of the evidence that income inequality is increasing as trade increases. Seven of the eight studies found moderate to significant increases in inequality; the eighth study found no change in income inequality. ${ }^{43}$ For example, one study by economists at the World Bank of 38 developing countries between 1965 and 1992 found that increased trade lowered income growth among the poorest $40 \%$ of the population as income grew in the rest of population. This study suggested that the cost of import substitution fell almost entirely on the poor and that the income inequality persisted over time. ${ }^{44}$

Another more recent study of 73 countries found that over a 20-year period of increased trade, intra-country inequality rose in 48 countries and decreased in nine. This study showed that inequality was rising in all regions of the world during the 1990s: the Central and Eastern European countries lost their middle class during the 1990s as they opened up their economies to foreign investment and trade. Most African countries were unable to increase economic growth significantly and continued to rely on exports of primary commodities with volatile prices. ${ }^{45}$ After a brief period of growth in the 1970 s, inequality in Latin America increased with successive waves of debt crises. The rapidly rising affluence of the urban elites in China and India

loans. Id.

42. For an excellent description of these methodologies and their biases, see Branko Milanovic, World Income Inequality in the Second Half of the 20th Century 3-42 (June 2001),

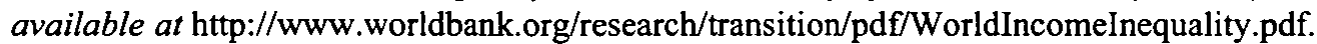

43. Robert Hunter Wade, The Rising Inequality of World Income Distribution, 38 FIN.\& DEV. 37, 38 (2001). For a contrasting view, see Nancy Birdsall, That Silly Inequality Debate, 130 FOREIGN POL'Y 92 (2002). Birdsall acknowledges that the inequality of average income has increased, because the industrialized countries are growing so rapidly. She argues that inequality is not important so long as the income level of the poor is rising in absolute terms. Id. at 92-94.

44. Mattias Lundberg \& Lyn Squire, The Simultaneous Evolution of Growth and Inequality 18-20, 27, World Bank (July 7, 2000), available at http://www.worldbank.org/research/growth/ pdfiles/squire.pdf.

45. Sali-i-Martin, supra note 39, at 2-3, 36-38. Sali-i-Martin argues that the slow rate of growth in Africa contrasted with rapid growth in China will contribute to growing global inequality, unless growth can be stimulated in the African countries. Id. at 38 . 
in response to the growth of exports was contrasted by the absolute poverty of the rural majority in those countries. ${ }^{46}$

In another study conducted by the World Bank, the Bank examined trends in income inequality between 1988 and 1993 based upon household survey data from all of the Bank's member states. This study included household income that might not otherwise be included in GDP per capita. We would expect that by including more household income this study would tend to understate the income gap between rich and poor countries. Nonetheless, this study showed that inequality in world income distribution increased by six percent within five years. ${ }^{47}$

The leading study to challenge these results was conducted for the World Bank by the economists David Dollar and Aart Kraay. It divided developing countries into two groups, "globalizers" and "nonglobalizers". The Dollar-Kraay study found that from 1990-2000 industrialized countries grew at an average annual rate of $2.2 \%$ GDP per capita, globalizing developing countries grew 5.0\%, and nonglobalizing developing countries grew $1.4 \%{ }^{48}$ In other words, the globalizers sprinted ahead of the non-globalizers and narrowed the income gap with the industrialized countries. Dollar and Kraay concluded that all developing countries should pursue greater openness to trade as a prescription for reducing world income inequality. ${ }^{49}$

There are a number of problems with the Dollar-Kraay study. First,

46. Giovanni Andrea Comia \& Sampsa Kiiski, Trends in Income Distribution in the PostWorld War II Period: Evidence and Interpretation, 2001 U.N. U. WORLD INST. FOR DEV. ECON. RES. DISCUSSION PAPER NO. 2001/89, 8-12, 15. By contrast, another study of 80 countries over 40 years reached the conclusion that trade increased economic growth and reduced poverty in poor countries. This study compared the income of the bottom $20 \%$ with the average GDP per capita. See David Dollar \& Art Kraay, Growth Is Good for the Poor 8-9, available at http://econ.worldbank.org/files/1696_wps2587.pdf (April 12, 2001). Other economists have criticized this study for omitting the effects of trade on the rest of the population. In particular, other economists have pointed out that the Dollar and Kraay study ignored the lost income of the Central and Eastern European middle class over the last decade as a result of globalization. See IDEAS Research Team, Globalisation and Income Inequality: A Survey, at http://www.networkideas.org/themes/Inequality/aug2002/ie19_Globalisation_Survey.htm (Aug. 19, 2002).

47. Branko Milanovic, True world income distribution, 1988-1993: First calculation based on household surveys alone, 112 ECON. J. 51, 72 (2002). This result confirmed an earlier study using different methodologies. Yuri Dikhanov \& Michael Ward, Measuring the distribution of global income, Towards a better understanding of the global distribution of income 8-10, World B a n $\quad(\mathrm{Feb}$ 2 2002$), \quad$ available at http://poverty.worldbank.org/files/13254_Towards_a_better_understanding_of_the_global.doc.

48. David Dollar \& Aart Kraay, Trade, Growth, and Poverty 27, at http://econ.worldbank.org/files/2207_wps2615.pdf (June 2001).

49. Id. at 4. See also David Dollar \& Aart Kraay, Spreading the Wealth, 81 FoREIGN AFFAIRS 120 (2002). 
the study was based on each country's GDP per capita calculated in terms of PPP and weighted by population. Due to the size of their populations, China and India together represent three-quarters of the sample. Thus, Dollar and Kraay's conclusion is based largely on their data showing that the GDP per capita in those countries rose faster than the GDP per capita in the industrialized countries or the non-globalizing developing countries. However, neither China nor India provided all the price data that the authors needed to construct the PPP. Instead, Dollar and Kraay estimated the PPP, which probably overstated the income of the poor for the reasons explained above. ${ }^{50}$ Moreover, Dollar and Kraay ignored the intra-country income distribution, which has dramatically increased in China. There is substantial evidence that China has one of the highest Gini coefficients, as a result of the way trade has benefited a small minority of urban workers and left the rural poor behind. ${ }^{51}$

50. Robert Hunter Wade, Globalization, Poverty and Income Distribution: Does the Liberal Argument Hold?, 2002 LSE WORKING PAPER SERIES NO. 02-33, 7-8, available at http://www.lse.ac.uk/Depts/destin/workpapers/worldshortinequalityjune02.pdf (unpublished draft on file with author). See generally, Dollar \& Kraay, supra note 46, at 2-5.

51. Intra-country inequality grew in China as a result of economic growth. The ratio of the average income of the wealthiest urban province to the poorest rural province rose from $7: 1$ to $11: 1$ in a decade. Robert Hunter Wade, supra note 50, at 18. By comparison, the ratio of the average income of Connecticut, the wealthiest state per capita, to Mississippi, the poorest state, is only about $2: 1$. In other words, regional income inequality in China increased to more than five times the regional income inequality in the United States.

In an earlier paper Dollar and Kraay examined the income distribution among 92 countries over four decades using Gini coefficients and concluded that economic growth and increased trade benefited the poor and did not necessarily increase inequality. See Dollar \& Kraay, supra note 46 , at $1-2,8-9$. There are a number of methodological problems with this paper. Gini coefficients tend to understate changes in inequality at either extreme of the income range. In addition, the study relied on the mean income of the bottom quintile and did not consider the effect of economic growth on the bottom decile. Moreover, the authors did not have complete data for many countries over the 40-year period, so they averaged income distribution over the period. Id. at 13-14.

Another study contradicted the conclusions of Dollar and Kraay. Sali-i-Martin found that although world income inequality declined from 1980-1998, there was substantial growth in intracountry inequality. Sali-i-Martin, supra note 39 , at 28-30.

There is overwhelming evidence that during the last two decades of increased trade wealth has become much more concentrated among the top income-earners in the richest countries. See generally, Ana M. Aizcorbe et al., Recent Changes in U.S. Family Finances: Evidence from the 1998 and 2001 Survey of Consumer Finances, 2003 FED. RES. BULL. 1, available at http://federalreserve.gov/pubs/bulletin/2003/0103lead.pdf. In the United States from 1980 to 1995, the top fifth of Americans saw their real income rise by $30 \%$, while the poorest fifth saw real income fall by $21 \%$. From 1979 to 1997 , the share of U.S. personal income held by the top one percent of Americans rose from 9.3\% to $16.6 \%$. KEVIN PHILliPS, WEALTH AND DEMOCRACY: A POLITICAL HISTORY OF THE AMERICAN RICH 127-29, 427 (2002). By 1998, the top $0.01 \%$ of all U.S. households, about 13,000 families, earned about as much as the 20 million poorest households. Paul Krugman, For Richer: How the Permissive Capitalism of the Boom destroyed American equality, N.Y. TIMES MAGAZINE, Oct. 20, 2002, at 62, 64, 65, 67. 
Second, the conclusions of the Dollar-Kraay study depended on which countries they characterized as "globalizers". The authors included China among the 24 globalizing developing countries. China alone represented more than $40 \%$ of the total population of the globalizing developing countries. ${ }^{52}$ Dollar and Kraay reported that during the 1990's China had the highest growth in GDP of any globalizing developing country $(8.6 \%)$. If China were omitted from the data, the results would have shown that the globalizers were not growing rapidly enough to lower the income gap with the industrialized countries. $^{53}$

Thus, the argument that trade reduces income inequality turns on the treatment of China as an open liberal market economy. Throughout the 1990 s, China has maintained a highly protected domestic market. Despite China's market reforms and privatization measures, statecontrolled enterprises remain a significant proportion of China's economy. China's privatized companies are largely run by communist party officials, and China's economy is riddled with corruption, waste, and huge government support for industry. If neo-liberal economists like Dollar and Kraay cannot produce evidence that trade is narrowing the global income gap outside of China, we should question the proposition that trade helps developing countries to narrow the gap.

Third, Dollar and Kraay did not have data on household income and economic growth for many developing countries. Instead, they filled in the gaps with averages, which may have biased their study. ${ }^{54}$ The economic growth figures for China were particularly suspect. They have been repeatedly revised downward, and even the Chinese government now claims that the $8 \%$ growth figure used by Dollar and Kraay was excessive. Other economists have estimated that China's economic growth was anywhere from $2 \%$ negative growth to at most $6 \%$ positive growth. ${ }^{55}$ If Dollar and Kraay had used more accurate growth figures, it is likely that their studies would have shown that global inequality increased.

During the last twenty years, the world's wealthiest countries have consumed a rapidly increasing share of world wealth, while the poorest

52. The other globalizers included Argentina, Bangladesh, Brazil, Colombia, Costa Rica, Dominican Republic, Haiti, Hungary, Ivory Coast, Jamaica, Jordan, Malaysia, Mali, Mexico, Nepal, Nicaragua, Paraguay, Philippines, Rwanda, Thailand, Uruguay, and Zimbabwe.

53. See Marc Lee, The Global Divide: Inequality in the world economy, 4 BEHIND THE NUMBERS 1, 6 (April 18, 2002), available at http://www.networkideas.org/featart/apr2002/ The_Global_Divide.pdf.

54. Wade, supra note 50 , at 7 .

55. Id. at 17-18. 
nations have consumed a shrinking share of world wealth. ${ }^{56}$ The most obvious cause of this growing global inequality is the increased volume of world trade and investment or globalization.

There are several ways that trade has contributed to this growing income gap. First, not all countries participate in the global economy to the same extent. The seven largest industrialized countries containing $10 \%$ of the world's population account for roughly $50 \%$ of the world's exports, while the poorest countries containing $40 \%$ of the world's population account for less than $3 \%$ of the world's exports. ${ }^{57}$ Total merchandise exports of all developing countries represented just $29.1 \%$ of world merchandise exports in 2001. ${ }^{58}$ Although the total value of merchandise exports from all developing countries grew by $9 \%$ from 1990-2000, this growth in trade was not shared among all developing countries. ${ }^{59}$ Five developing countries, accounted for nearly half of all the increase in merchandise exports among developing countries in $2001 .^{60}$ The aggregate value of all merchandise exports from the fortynine least developed countries in 2000 was only slightly more than Poland's merchandise exports for that year. ${ }^{61}$ Most developing countries have not enjoyed significant increases in exports because they rely on primary product exports, and the market for primary products is limited. Industrialized countries protect their own farmers from imports with generous farm subsidies and tariffs. ${ }^{62}$ Agricultural subsidies, which are

56. Countries representing the wealthiest $20 \%$ of the world's population now earn more than $80 \%$ of the world's GDP. Kevin Watkins, Trade, globalization and poverty reduction: Why the rules of the game matter at 3, Carnegie Endowment for International Peace, Seminar on World Trade and Poverty (July 2, 2002), available at http://www.maketradefair.com/assets/english/ Kevin_Watkins_Carnegie.pdf. The ratio of the average income of the world's top ten percent income earners to the world's bottom ten percent has rapidly increased from $86.2 \%$ in 1980 to $148.8 \%$ in 1999. Christian E. Weller et al., The Unremarkable Record of Liberalized Trade at 7, Economic Policy Institute, Briefing Paper (Oct. 2001), available at http://www.epinet.org/briefingpapers/ Sept01 inequality/Sept0linequality.pdf. The ratio of the real GDP per capita in PPP of the top $20 \%$ of states to that of the bottom $20 \%$ of states is roughly 25 or 30:1. By comparison, the average ratio of the top to the bottom quintile within any given state is only 5:1. Robert Hunter Wade, supra note 40, at 4.

57. Watkins, supra note 56 , at 3.

58. WTO, INTERNATIONAL TRADE STATISTICS 2002, supra note 38 , at 5.

59. Id. at 6.

60. Id. at 5-6.

61. WTO, INTERNATIONAL TRADE STATISTICS 20014 (2001), available at http://www.wto.org/ english/res_e/statis_e/its2001_e/stats2001_e.pdf.

62. The average tariff of industrialized countries' on imports from developing countries is about $25 \%$ higher than the average tariff on imports from other industrialized countries. Id. at 3. Only $6 \%$ of the tariff rates listed in the U.S. tariff schedule exceed $15 \%$, but they cover $14 \%$ of all exports from developing countries, as compared to $3 \%$ of exports from industrialized countries. Watkins, supra note 56, at 4. For example, the U.S. tariff on groundnuts from Uganda is $160 \%$ ad valorem. 
legal under the GATT, also keep developing countries' primary products out of foreign markets. As a result, most of the economic growth occurred in a few countries in Latin America and Asia with large increases in exports.

Another reason that developing countries have not gained more from international trade is that primary products are the principal export of most developing countries, and world prices for primary products in constant dollars have not increased. ${ }^{63}$ The WTO has both removed some of the barriers to trade in agriculture and has opened up developing countries to more service exports. The effect has been to increase dependence on the export of primary products increasing the supply and lowering the price. Most developing countries import secondary products, and the real prices of secondary products have increased. As a result, most developing countries face declining terms of trade. In other words, developing countries are compelled to work harder to earn less foreign exchange to pay for increasingly expensive imports.

Trade also has an adverse effect on developing countries' growth by increasing capital volatility. As tariff and non-tariff barriers to trade are removed, there is no longer an incentive for companies to locate their operations in the target market to get behind any trade barrier. Companies can move their operations anywhere and export to the target market. On the one hand, developing countries often benefit when companies move manufacturing from high-wage industrialized countries to low-wage developing countries. Foreign investment creates jobs, improves productivity, introduces new technologies, diversifies a developing country's economy, increases access to foreign markets, and may increase foreign exchange earnings. However, foreign investors demand competitive returns for their capital, and in the global economy, capital can move quickly to new labor markets. ${ }^{64}$ A sudden loss of foreign capital can create economic dislocations and large sunk costs for a developing country. ${ }^{65}$

At the same time, the growth of the international capital market has

63. During the period from 1990 to 2000 , export prices of all primary commodities fell at various points by as much as $14 \%$ and ended the decade where they had started. WTO, supra note 38 , at 212. During this period inflation seriously eroded the purchasing power of countries that relied on primary product exports.

64. See generally, William GREIDER, ONE WORLD, READY OR NOT: THE MANIC OF Global CAPITALISM (1997); EDWARD LUTTWAK, TURBO-CAPITALISM (1999).

65. Mexico is a vivid example of how capital movement hurts developing countries. In 2001, the Mexican Government estimated that it lost $5 \%$ of its manufacturing jobs, when foreign investors moved plants to China. As a result 580,000 Mexican workers lost employment, and over 350 maquiladoras closed, causing economic dislocation. Barry C. Lynn, Trading With a LowWage Tiger, 14 The AM. Prospect 10 (2003). 
encouraged the growth of financial services in the industrialized countries. The enormous wealth created by these companies has accrued to the benefit of a small number of people in financial centers like New York, Tokyo, and London. The same economic forces that generate successive financial crises in the developing world yield vast fortunes for a privileged few in the industrialized world.

Other social phenomena besides trade may contribute to growing inequality: more households are headed by women, especially in urban societies, and because women generally earn less than men, this change has led to an increase in the number of poor families; the productivity and wages of some workers has increased due to new technologies that are not available to all workers; the expansion of the service sector has placed a premium on highly-skilled workers, enabling the best educated workers to command much higher salaries; population growth among the rural poor in developing countries has reduced the real GDP per capita; the expansion of the international capital market has created large rewards for investors and has led to a succession of debt crises, which have impoverished developing countries; the growth of organized crime and corruption in the transitional economies of the postcommunist world and the developing countries has increased the concentration of wealth in the hands of a few. ${ }^{66}$ Each of these phenomena probably influences global inequality, but each of them is closely related to the growth in trade. Trying to disaggregate these causes from the impact of trade on income distribution may be futile.

First, trade has influenced changes in family structure in urban societies. In industrialized countries, import competition has displaced manufacturing jobs that pay good wages. Unemployment may lead to an increase in divorce and a postponement of marriage. ${ }^{67}$ As men lose jobs, more women are forced into the job market to support their families. In developing countries the export sector often prefers female labor. Export industries view women as more productive workers, better at repetitive work, and less likely to unionize or demand higher wages. ${ }^{68}$ In Mexico, for example, most of the workers in the maquiladora plants are women. ${ }^{69}$ In effect, men in the industrialized countries are losing wellpaid manufacturing jobs to women in the developing countries, who are

66. See Gary Burtless, Worsening American Income Inequality: Is world trade to blame? 14 BROOKINGS REV. 26, 26-31 (1996).

67. See JOAN WILlIAMS, U NBENDING GendeR: Why FAMILY AND WORK CONFLICT AND WHAT TO DO ABOUT IT (2000).

68. SASKIA SASSEN, GLOBALIZATION AND ITS DISCONTENTS 111-20 (1998).

69. ANNETTE FUENTES \& BARBARA EHRENREICH, WOMEN IN THE GLOBAL FACTORY 29 (1983). 
paid substantially less. As more women enter the work force both in industrialized and developing societies, families become dependent upon working mothers. Women-led households are likely to have lower income because women are paid less than men. The increase in female heads-of-households has led to the feminization of poverty in industrialized and developing countries alike. In post-communist transitional economies the process of privatization has hurt women disproportionately. As companies are forced to cut costs by discharging redundant workers, the post-communist owners typically fire women first. In the absence of a strong legal regime to enforce laws against gender discrimination, transitional economies have routinely displaced female workers while the public welfare system has been abandoned. The result is a dramatic increase in poverty among women in postcommunist societies as a result of globalization. ${ }^{70}$

Second, import competition has sparked innovation and led to new technologies that have increased productivity and cut costs. As prodictivity increases, so do salaries in those industries served by higher technologies. Higher-skilled workers in high-technology industries are the primary beneficiaries of the increase in competition and innovation. ${ }^{71}$ Some workers are displaced by technology; some workers lack the skills or training to use new technology; some industries are not suited for technical innovation and wages in these industries lag behind. As trade has increased the pressure to introduce new technologies, it has widened the income gap between workers with the skills and access to new technology and workers without.

Third, trade has accelerated the shift from a manufacturing base to a service economy in the industrialized countries. The service sector rewards the best-educated workers, who have the knowledge valued in the global market, with the highest wages. There is a strong correlation in industrialized countries between income and educational level. The shift to a single world market and the increased capacity to move

70. Joel R. Paul, Cultural Resistance to Global Governance, 22 MiCH. J. INT'L L. 1, 82 (2000); Francis Elisabeth Olsen, Feminism in Central and Eastern Europe: Risks and Possibilities of American Engagement, 106 Y ALE L.J. 2215, 2236 (1997); Nicki Negrau, Listening to Women's Voices: Living in Post-Communist Romania, 12 CONN. J. INT'L L. 117, 134-38 (1996); Emily Stoper \& Emilia Ianeva, Democratization and Women's Employment Policy in Post-Communist Bulgaria, 12 CONN. J. INT'L L. 9, 20-26 (1996); Elizabeth Messud, Russian Women and Women's Rights: A Case Study in Universalist/Cultural Relativist Debate, 12 CONN. J. INT'L L. 77, 101 (1996).

71. Different skill levels explain part, but not all of the growing income disparity. To some extent this skill-bias is a result of higher returns to education over time. Jeffrey Gordon, Employees, Pensions, and the New Economic Order, 97 ColuM. L. REV. 1519, 1526 (1997). See generally, ROBERT REICH, WORK OF NATIONS 81-87 (1992). 
people, things, and ideas rapidly through transportation or telecommunications have raised the rewards for top-income earners. Those at the top of their industry or profession can sell their product to a world market leaving competitors behind to occupy small and specialized local niche markets. ${ }^{72}$ In a winner-take-all society, wealth is increasingly more concentrated in the hands of a few, contrary to the claims of WTO proponents that trade will lift all boats. ${ }^{73}$ As a result, workers without post-secondary education are being left further behind by increased trade in services.

Fourth, increased trade has contributed to shifts in population growth in industrialized and developing countries, which also exacerbates income inequality in the following ways. In industrialized countries, for the reasons discussed above, more women are working. Working women have tended to have fewer children. Most industrialized countries have witnessed a remarkable drop in fertility rates that has led to slow growth or even negative growth in population. As long as the population is growing slower than the GDP, the GDP per capita in industrialized countries is increasing.

In developing countries, increased trade has transformed the lives of many women resulting in increased literacy rates and more educational opportunities, at least for urban women employed in the export sector. Better-educated urban women in developing countries are more likely to practice birth control and limit family size. ${ }^{74}$ At the same time, population growth among the rural poor has continued unabated. As commerce has increased awareness of, and contact with, rural regions of the developing world, it has also brought with it improvements in child mortality rates and lengthened the adult life span. The result is that population shifts are in favor of more poor and fewer middle-class workers in developing countries. The impact of trade on population growth in developing countries has lowered per capita GDP. As a consequence of globalization, lower birth rates among the affluent and higher birth rates among the poor contribute to the growth of income inequality.

72. In 1969 the ratio of the average pay of a chief executive officer at one of the 800 largest U.S. corporations to the pay of an average production worker was $25: 1$. By 1988 the ratio had risen to $93: 1$, and by 1999 the ratio stood at $419: 1$. The average compensation package of the CEOs at the largest corporations had risen nearly $500 \%$ between 1990 and 1998 to an average of $\$ 10.6$ million. At the same time median real wages remained relatively flat, and corporate profits rose only $110 \%$ for the same companies. PHILLIPS, supra note 51, at 153 .

73. See generally, ROBERT H. FRANK \& PHILLIP J. COOK, THE WINNER-TAKE-All SOCIETY (1995).

74. AMARTYA SEN, DeVElOPMENT AS FREEDOM 198-99 (1999). 
Fifth, the growth of international capital markets has paralleled the increase in trade. Free trade makes it possible and desirable for capital to migrate to countries with the lowest cost of production; trade has created new wealth for investment; and trade has led to the consolidation of many industries, which requires huge amounts of capital. As the international capital market has expanded, it has enriched the small number of elite workers who broker that market in financial capitals like New York, Tokyo, and London. At the same time, global capital has demanded ever-increasing rates of return from ever-riskier investments. ${ }^{75}$ Developing countries have become more dependent upon foreign investment to provide them with the technology and infrastructure that would allow them to compete more effectively in the global market. Developing countries, facing declining terms of trade, are often unable to repay their foreign debt leading to a series of debt crises. ${ }^{76}$ With each successive debt crisis, developing countries lose foreign investment and exchange rates decline. The International Monetary Fund and foreign banks often insist that as a condition for further loans, developing countries must cut social services to balance their budgets, accelerate privatization, and eliminate trade barriers. The burden imposed by these conditions often falls on the backs of those least able to absorb them. In this way, increased trade has aggravated global income inequality by profiting financial centers and burdening the world's poor.

Finally, trade has contributed to the growth of criminal syndicates and corruption, which have led to a concentration of wealth in developing and transitional economies. As multinational companies compete for access to new markets for exports and investment, they have increased the opportunities for corrupt public officials to profit. In formerly communist countries, the rush toward privatization and open markets created enormous opportunities for criminal elements. ${ }^{77}$ Organized crime flourished. Globalization facilitated illicit trade in slavery, prostitution, drugs, guns, and diamonds. The result is that trade created a new criminal elite who have made easy fortunes at the expense of their countries.

Globalization has brought many benefits to developing countries, but as it does so, it raises popular expectations among consumers and workers that may be disappointed. The growing disparity of wealth

75. See generally, GREIDER, supra note 64 , at 43-53, 297-306.

76. See id. at 306-15.

77. Paul B. Stephan, Rationality and Corruption in the Post-Socialist World, 14 CoNN. J. INT'L L. 533, 540-46 (1999). 
among rich and poor countries means that the benefits of trade are not shared equitably. The disparate distribution of the gains from world trade undermines popular support for international trade institutions by contradicting the claim that international trade benefits everyone. The gap between the expectations of the populace and the reality of poverty creates political instability that may threaten the global order. An island of affluence surrounded by an ocean of poverty feels no security in a rising tide.

\section{Trade In the Presence of Market Failures or Distortions}

Globalization proponents defend international trade institutions as engines of economic growth and development. I have argued that these institutions do not necessarily increase growth nor do they share the benefits from trade equitably. Neo-liberal economists acknowledge these problems with the market. They admit that some form of government intervention in the market may be justified under some circumstances.

According to the theory of the second best, ${ }^{78}$ free trade is not efficient in the presence of a market failure or market distortion. A market failure exists when there are external social costs or benefits (externalities) that are not reflected in the price of a good. For example, if a steel mill pollutes the surrounding farmland, we would expect that the true social cost of production was not reflected in the price of steel in the absence of government intervention. When prices do not reflect the true cost of production resources are not allocated efficiently; that is, society may be wealthier if we produced less steel, or none at all, and instead exploited valuable farmland. Perhaps it would be more efficient in this situation to produce farm products and import steel. Neo-liberal economics would counsel that when there are external social costs, the government should intervene to shift the cost of pollution from the farmers to the manufacturer, for example, by imposing a fine or a tax. Government intervention forces the manufacturer to internalize the social cost, and the manufacturer will pass the cost on to the consumer in higher steel prices. In this way, the price of steel will reflect the true social cost of production, as well as the manufacturer's private costs.

A market distortion exists when the government intervenes in a market in the absence of any externalities disturbing an otherwise competitive price. For example, the government subsidizes sugar

78. Richard Lipsey \& Kelvin Lancaster, The General Theory of Second Best, 24 REV. ECON. STUD. 11 (1956). 
farmers because of the political influence of the sugar lobby. These subsidies may distort comparative advantage by making it appear that U.S. sugar farmers are more efficient, leading to an inefficient allocation of resources.

When there are market distortions or market failures, the economy is not operating efficiently. Economists would say we have sub-optimal or a second-best equilibrium. In this situation, the theory of the second best teaches that appropriate government intervention to correct the market failure or distortion will improve efficiency. The difficulty is to determine the appropriate form of government intervention in each situation. To decide how to intervene, we need to distinguish between two kinds of market distortion or failure. There may be distortions or failures caused outside the national economy. For example, a foreign firm may be engaged in dumping products below cost, or a foreign government may be subsidizing exports. These external distortions are beyond the control of the importing country. Alternatively, market failures or distortions may be internal. For example, the domestic government may subsidize domestic agriculture.

Most neo-liberal economists would respond to market failures or distortions by recommending that internal distortions or failures should be corrected domestically, leaving free trade unobstructed. External market failures or distortions cannot be cured domestically, however. If market failures or distortions cannot be corrected, free trade may cause further distortions and reduce economic growth. In such circumstances, an importing country should protect its domestic industry with tariffs and quotas. ${ }^{79}$

In reality, there are several problems in determining the correct response to a market failure or distortion. The line between internal and external market failures or distortions is often hard to draw: One country's distortion may be in response to another's; a market failure may occur across borders; industries operating in multiple jurisdictions may be subject to numerous market failures and distortions in more than one country; government subsidies are often difficult to identify; and economists do not agree on a precise definition of subsidies.

Moreover, the neo-liberal response makes good economic sense, but it sometimes runs contrary to the policies of the international trade institutions and the political realities of globalization. These market

79. JAGDish BHAGWATI, FREE TRADE TODAY 11-33 (2002). Bhagwati has shown that most distortions can be corrected at the domestic level, but in some circumstances, for example where a country has sufficient market power to affect world prices, trade measures will improve a country's welfare. Id. at 26-28. 
failures or distortions are often built into the architecture of globalization. The WTO rules, in particular, often permit, or in some cases require, government measures that seriously distort market prices. Many of these distortions cannot be corrected, and as a result, they call into question the fundamental premise that the WTO can effectuate economic growth through free trade. Alternatively, in other circumstances the WTO prevents states from acting appropriately to correct external market distortions and failures. In these ways, the WTO may distort the allocation of productive resources and reduce economic growth.

The GATT, which was adopted in 1947, established rules for regulating the import and export of goods, negotiating trade concessions, and settling disputes. In 1994 the Uruguay Round Agreements established the WTO, amended the GATT, and added new agreements covering dispute settlement (DSU) and the regulation of services (GATS), intellectual property rights (TRIPS), agriculture, and human, animal, and plant health and safety (SPS), among other subjects. The core commitments and basic rights contained in the 1947 GATT remain unchanged in the 1994 GATT. All 145 WTO members are parties to the GATT, the DSU, the multilateral agreements, GATS, and TRIPS.

The GATT rules both permit some market distortions by allowing governments to discriminate against imports and prevent governments from correcting some market failures. In other words, the GATT is too restrictive in some respects and too permissive in others. As a consequence, the GATT may discourage an efficient allocation of resources and could lead to a sub-optimal result. That does not mean that the world would necessarily be wealthier without the GATT. It does call into question the assertion of WTO proponents that the WTO actually increases the world's wealth.

There are at least four ways in which the GATT distorts comparative advantage. First, in certain respects the GATT requires liberalization measures, even where there are external distortions that would justify some protectionism (e.g., GATT prohibitions on export subsidies and quotas). Second, the GATT authorizes certain protectionist measures that maintain inefficient industries (e.g., GATT safeguards). Third, the GATT permits certain trade preferences that distort the pattern of trade, (e.g., regional trade agreements (RTAs), like the NAFTA and the EU). Fourth, in certain circumstances the GATT mandates that countries undertake measures that limit competition (e.g., TRIPS protection for intellectual property rights). 


\section{A. GATT Requires Liberalization, Even in the Presence of External Distortions}

The core commitment underlying the GATT is the obligation not to discriminate against imports based upon their country of origin. Left to their own devices, most national governments might favor domestic industries by protecting them from import competition. In theory, GATT's non-discrimination principle allows market forces to determine the pattern of trade, and in this sense, it facilitates the operation of comparative advantage.

WTO members commit themselves not to discriminate either among imports from other members ${ }^{80}$ or between imported products that have entered their territory and domestic products. ${ }^{81}$ To this end the GATT generally prohibits WTO members from increasing tariffs ${ }^{82}$ or imposing import or export quotas. ${ }^{83}$ In addition, WTO members are not permitted to provide specific domestic subsidies that aid any specific importcompeting industry or any export subsidies for non-primary products, such as manufactured goods or processed foods. ${ }^{84}$

Generally, these prohibitions do not take into account the presence of market failures or distortions that might justify some government intervention. For example, if a steel manufacturer cannot compete with cheap imported steel because the domestic manufacturer is subject to expensive environmental regulations that do not apply to the foreign manufacturers, we might conclude that we have a market failure, (i.e., the foreign steel has external social costs that are not being internalized). The government should either subsidize the domestic manufacturer to pay for the cost of environmental regulation or tax the importer to create a level playing field. GATT would prohibit either of these measures, however. To the extent that the GATT limits the ability of governments to respond to market distortions, the GATT may reduce economic growth.

80. General Agreement on Tariffs and Trade, Oct. 30, 1947, 61 Stat. A-11, T.I.A.S. 1700, 55 U.N.T.S. 194, art. I [hereinafter GATT].

81. Id. II(1)(b).

82. Id. art. II.

83. Id. art. XI.

84. Id. art. XVI; Agreement on Subsidies and Countervailing Measures, Apr. 15, 1994, Marrakesh Agreement Establishing the World Trade Organization, Annex 1A, THE RESULTS OF THE URUguay ROUND OF Multilateral TRADE NEgOtiations: THE Legal TEXTS 264-314 (1994). 


\section{B. GATT Authorizes Certain Protectionist Measures}

Proponents of GATT argue that it disciplines national governments to prevent protectionism. It is true that GATT imposes limits on governments that would otherwise be free to discriminate against foreign imports. However, GATT also legitimates protectionist measures in some circumstances. The basic GATT rules summarized above are subject to numerous exceptions that authorize states in some circumstances to use tariffs, quotas, and subsidies to protect domestic industries.

For example, the GATT authorizes states to adopt safeguard measures if an increase in imports causes or threatens serious injury to domestic producers of like or directly competitive products. ${ }^{85}$ The assumption is that protected industries will use this temporary safeguard to adjust to imports, either through innovation or by shifting resources to some other productive activity. In fact, nothing in the Agreement on Safeguards or the U.S. domestic statute actually conditions the grant of a safeguard on a commitment to make adjustments.

Safeguards are obviously incompatible with the operation of comparative advantage. Comparative advantage only works if less efficient industries are driven out of business, freeing resources for more efficient industries. Safeguards effectively cancel the operation of comparative advantage by protecting the weak and maintaining an inefficient allocation of resources. Individual WTO members are most likely to implement safeguards to protect their largest and most politically influential constituent industries, causing harm to other exporting countries and rewarding rent seeking. Member states abuse this safeguard provision to protect politically powerful industries that are unable to compete against imports. ${ }^{86}$ For example, in March 2002, President Bush imposed safeguards to protect the U.S. steel industry with a wide-ranging impact on world steel production. The President imposed tariffs up to $30 \%$ on roughly 24 million tons of imported steel worth more than $\$ 10$ billion for three years. The EU, Brazil, China, Japan, New Zealand, Norway, South Korea, and Switzerland filed a

85. GATT, supra note 80, art. XIX; Agreement on Subsidies and Countervailing Measures, supra note 84 , at $315-24$.

86. The Appellate Body has tried to restrict the use of safeguards. See, e.g., Argentina-Safeguard Measures on Imports of Footwear, WT/DS121/AB/R, 1999 WL 1201339 (WTO Dec. 14, 1999); United States-Definitive Safeguard Measures on Imports of Wheat Gluten from the European Communities, WT/DS166/AB/R, 2000 WL 1911912 (WTO Dec. 22, 2000); United States-Safeguard Measures on Imports of Fresh, Chilled or Frozen Lamb Meat from New Zealand and Australia, WT/DS178AB/R, 2001 WL 470667 (WTO May 1, 2001). 
complaint with the WTO Dispute Settlement Body (DSB) claiming that the U.S. safeguards violated the Agreement on Safeguards. ${ }^{87}$ Most authorities agreed that the United States has a weak case, but President Bush was motivated in part by the electoral importance of the key steelproducing states. U.S. steel manufacturers have received import protection and subsidies in the past, and they have been unable or unwilling to consolidate and re-tool the industry to make it more competitive. A panel decision ruled that the U.S. safeguards violated the GATT, ${ }^{88}$ and the United States has filed an appeal. While a final resolution is still pending, the United States has continued to impose GATT-illegal tariffs on steel imports with impunity since March 2003. In the meantime, the EU has responded to the U.S. safeguards by adopting their own safeguards to prevent a surge of steel imports displaced from the U.S. market. Both the U.S. and the E.U. safeguards have significantly distorted world steel prices.

Subsidies are another example of how GATT legitimates protectionist measures. Although the GATT generally prohibits export subsidies and specific domestic subsidies, it expressly permits WTO members to provide domestic and export subsidies for agricultural products. ${ }^{89}$ Agricultural subsidies are used primarily by industrialized countries to maintain their agricultural sector. Agricultural subsidies are subject to a schedule of commitments under the 1994 Agreement on Agriculture, which is intended to gradually reduce these subsidies over a period of years. It also exempts certain agricultural subsidies from being subject to countervailing duties that would neutralize their effect. Nevertheless, the EU, the United States, Canada, and Japan continue to provide extensive and expensive subsidies that have distorted the agricultural market and seriously disadvantaged primary products exported from developing countries. As of 2000, according to the Organization of Economic Cooperation and Development (OECD), the

87. Robert Zoellick, U.S. Trade Representative Steel Press Briefing (Mar. 5, 2002), available at http://www.whitehouse.gov/news/releases/2002/03/20020305-10.html; WTO Issues Preliminary Ruling Striking Down U.S. Steel Safeguard, 20 Int'l Trade Rep. (BNA) No. 13, at 577 (March 27, 2003).

88. United States-Definitive Safeguard Measures on Imports of Certain Steel Products, Final Report of the Panel, WT/DS248/R (adopted July 11, 2003).

89. GATT, supra note 80 , art. XVI(B)(3) provides that "parties should seek to avoid the use of subsidies on the export of primary products," and such subsidies "shall not be applied in a manner which results in that contracting party having more than an equitable share of world export trade in that product." The 1994 Agreement on Subsidies and Countervailing Measures prohibits only export subsidies and subsidies to consumers for purchasing domestic products over imported goods, subject to the Agreement on Agriculture. Agreement on Subsidies and Countervailing Measures, supra note 84, at 266, art. 3. 
industrialized countries provided a total of $\$ 327$ billion in agricultural subsidies. ${ }^{90}$ That amount represents more than $1 \%$ of the GDP among all industrialized (OECD) countries. ${ }^{91}$ The impact of this magnitude of subsidies on agriculture worldwide is undeniable. In 2000, agricultural support for producers in the OECD countries equaled $34 \%$ of total farm receipts. ${ }^{92}$ These agricultural subsidies are both an enormous expense for taxpayers and highly distorting. They also create an insurmountable barrier to many agricultural imports from developing countries with the consequence of impoverishing much of the world's population.

Developing states, which represent the majority of WTO members, are allowed numerous exceptions to assist their development. For example, developing states can provide subsidies for export industries that are otherwise illegal for industrialized states. ${ }^{93}$ The GATT permits a state to safeguard its foreign exchange and balance of payments, which is a particular concern to developing countries, by imposing either quantitative restrictions ${ }^{94}$ or exchange controls. ${ }^{95}$ WTO members are authorized to establish state trading enterprises, which can exercise monopoly power over imports and exports. ${ }^{96}$

In addition, the GATT contains a laundry list of general exceptions for all WTO members. For example, states may use quantitative restrictions to regulate the grading and marketing of commodities and protect agricultural price-support programs,${ }^{97}$ public morals, human, animal or plant life or health, intellectual property rights, and natural resources. ${ }^{98}$ States can also use quantitative restrictions to implement multilateral commodity agreements, like OPEC. ${ }^{99}$ The GATT allows a state to take "any action which it considers necessary for the protection

90. WTO, ANNUAL REPORT 2002, 35 (2002).

91. Agricultural Policies in OECD Countries: Monitoring AND Evaluation 9 (2002). Coincidentally, the size of agricultural subsidies in industrialized countries is roughly equivalent to the empirical measurements of the gains from trade discussed above. In other words, the gains from trade are being expended to protect agriculture in industrialized countries from developing countries' primary product imports.

92. WTO, supra note 90, at 35. According to the OECD Producer Support Estimate, U.S. farmers received $21 \%$ of their revenue from government subsidies; EU farmers received $35 \%$ of their revenue from subsidies; and Japanese farmers received $59 \%$ of their revenue from subsidies. Anne Effland et al., Commodity Policies of the U.S., EC. and Japan, AGRICULTURAL OUTLOOK (Dec. 2002), available at http://www.ers.usda.gov/publications/AgOutlook/Dec2002/.

93. GATT art. XVIII.

94. Id. art. XII.

95. Id. art. $\mathrm{XV}(9)$.

96. Id. art. XVII.

97. Id. art. XI, 2(b), (c).

98. Id. art. $\mathrm{XX}(\mathrm{a})-(\mathrm{g})$.

99. Id. art. $\mathrm{XX}(\mathrm{h})$. 
of its essential security interests" either relating to military weapons, war, international emergencies, or embargoes authorized under the United Nations Charter. ${ }^{100}$

The theory of the second-best suggests that there may be circumstances under which some of these exceptions are economically justified to correct for an internal or external market failure or distortion. However, states employ these exceptions in response to domestic political pressure without regard for whether there are market failures or distortions that could be remedied internally. The GATT's broad principle of non-discrimination is riddled with exceptions that empower states to pursue protectionist policies that promote inefficiency.

\section{The GATT Permits Certain Trade Preferences That Distort Trade Patterns}

Perhaps the single most significant exception to the nondiscrimination principle is the right of states to grant preferential tariff concessions to imports from other states within the same customs union or free-trade area. ${ }^{101}$ The WTO has received formal notice of 159 regional trade agreements (RTAs). In $2001,43 \%$ of world merchandise exports was traded on preferential terms within one of the seven major RTAs. ${ }^{102}$ This preferential intra-regional trade permanently disadvantages imports from all extra-regional countries. The sheer size of the EU and NAFTA, which together purchase $62.4 \%$ of the world's total merchandise imports, diverts the pattern of world trade to a significant degree. ${ }^{103}$

Economists disagree whether a customs union or free-trade area increases the overall volume of trade enough to justify the loss of

100. Id. art. XXI. Under this provision, the United States has restricted trade for foreign policy or national security reasons or in compliance with the United Nations with 19 countries, and it has imposed a broad range of export restraints on technology and goods related to national security.

101. Id. art. $\mathrm{XXIV(5).} \mathrm{A} \mathrm{customs} \mathrm{union} \mathrm{or} \mathrm{territory} \mathrm{refers} \mathrm{to} \mathrm{an} \mathrm{agreement} \mathrm{between} \mathrm{two} \mathrm{or}$ more countries to reduce or eliminate tariffs between them and to maintain a common external tariff. The European Union is an example of a customs union. A free-trade area refers to an agreement between two or more countries to reduce or eliminate tariffs between them without imposing a common external tariff. In NAFTA, for example, an import from Japan would be subject to different tariffs depending upon whether it entered Canada, Mexico, or the United States.

102. The seven major RTAs include the EU, NAFTA, ASEAN, MERCOSUR, CEFTA, APEC and ANDEAN. WTO, INTERNATIONAL TRADE STATISTICS 2002, supra note 38, at 29. Altogether, there are over 400 agreements granting preferential tariffs currently in effect.

103. Id. at 41 . 
efficiency from trade diversion. ${ }^{104}$ That question can only be answered empirically for each particular case. Regardless of the empirical evidence, free-trade areas and customs unions are inconsistent with the principle of comparative advantage and nondiscrimination. While the creation of a customs union or free-trade area is potentially beneficial to its members, it hurts countries excluded.

The structure of the GATT and the WTO actually encourages the formation of free-trade areas and customs unions in at least two respects. Free-trade areas and customs unions trigger the formation of more regional trading blocs because parties outside the regional trade bloc need to counter the loss of trade that results from being excluded. ${ }^{105}$ In addition, WTO members gain negotiating leverage within the trading round and the capacity to pressure other members to comply with WTO panel decisions by merging their domestic markets. In this manner the GATT and the WTO reward countries for forming regional trade blocs. The proliferation of regional trade agreements, which was not foreseen by the founders of the GATT, has seriously distorted comparative advantages. ${ }^{106}$

Other trade preferences are also tolerated or encouraged by the GATT. Former European colonial powers maintain trade preferences for their former colonies, ${ }^{107}$ and developing countries are also entitled to receive preferential tariff rates from industrialized states. ${ }^{108}$

\section{The WTO Mandates that Countries Undertake Measures that Limit Competition}

The WTO requires member states to protect intellectual property rights held by non-nationals. The WTO TRIPS Agreement obligates all member states to adopt laws that conform to the international treaties on copyright, patents, and trademark, and to enforce the laws equitably to protect the rights of non-nationals. Intellectual property law authorizes rights holders to exclude competing goods that infringe on their rights from the national market and to obtain financial compensation for lost sales due to such infringement. ${ }^{109}$ Most drugs, chemicals, scientific

104. JACOB VINER, THE CUSTOMS UNION ISSUE 41 (1950). Viner showed that the trade diversion caused by free-trade areas and customs unions may reduce the welfare of countries both inside and outside by distorting the allocation of productive resources. Id. at 48-51.

105. Paul R. Krugman, Is Bilateralism Bad?, in INTERNATIONAL TRADE AND TRADE POLICY 9, 12 (Elhanan Helpman \& Assaf Razia eds., 1991).

106. JAGDISH BHAGWATI, supra note 79, at 106-20.

107. GATT, supra note 80 , art. I(2)(b).

108. Id. Part IV.

109. Arguably, some level of protection for intellectual property rights for some limited 
products, mechanical devices, electronics, tools, vehicles, telecommunications, textiles, and many agricultural products, designs, and artistic creations are protected by patents, or were at one time. Nearly all consumer goods are protected by trademarks, and most written materials, sound recordings, film, and software are protected by copyright. The vast majority of merchandise goods traded on world markets are, or were once, protected by intellectual property rights. That leaves most primary products and some secondary products sold to processors unprotected.

The purpose of granting a copyright or patent, which allows one party to exclude others from competing for a limited time, is to create an incentive for invention. In theory, the state must strike a balance between the twin objectives of encouraging competition and sparking invention by limiting the terms and conditions of the intellectual property right. In principle, some level of protection for intellectual property rights for a limited period could be efficient, but there is no theoretical basis for determining a priori what the proper level of protection is for all goods. In reality, there is substantial evidence that the existing rules for patents and copyrights are overly protective, providing a larger reward than is necessary and stifling competitive forces. ${ }^{110}$

The distorting effect of intellectual property rights must be considered in light of the trading relations between industrialized and developing countries. Most developing countries export primary products or some basic manufactured goods. ${ }^{11}$ Often, these basic manufactured goods are no longer protected by patents or trademarks. To a large extent these exports are homogenous and are sold in a relatively competitive market, except to the extent that the agricultural market generally is distorted by subsidies or to the extent that importing countries provide tariff protection for their domestic producers.

period of time could be efficient, but of course, there is no basis for determining a priori in all circumstances that the existing rules are efficient.

110. See generally, Robert P. Merges \& Richard R. Nelson, On the Complex Economics of Patent Scope, 90 COLUM. L. REV. 839 (1990); Stephen Breyer, The Uneasy Case for Copyright, 84 HARV. L. REV. 281 (1970); Robert P. Merges \& Glenn Reynolds, The Proper Scope of the Copyright and Patent Power, 37 HARV. J. ON LEGIS. 45 (2000).

111. Fifty years ago primary products represented more than $90 \%$ of developing countries' export earnings. By 2000 , primary products represented less than $30 \%$ of developing countries' export earnings. That statistic is misleading, however. Most of the change occurred in the composition of exports of the newly-industrialized Asian countries. In Africa, by contrast, primary producers still represent nearly $90 \%$ of export earnings. Out of 111 developing countries, only 27 earned more from the export of manufactured good than primary products in 2000 . WTO, supra note 90 , at $18-21$. 
Developing countries often cannot afford extensive export subsidies, and they do not have leverage in international markets. World commodity prices tend to be unstable, and over the long term, commodity prices have declined in real terms. The result is that developing countries sell their exports competitively priced, and generally those prices have not risen over time. By contrast, the industrialized countries export products that are largely protected by trademarks, patents, or copyrights. These exports are not homogenous goods. There may be substitutable goods that are nearly the same or closely related, but exporters rely on trademarks to convince consumers that these differences really do matter.

The development of TRIPS has created two quite distinct trading regimes within the WTO. On the one hand, the competitive market regime embodied in the GATT is intended to ensure that homogenous goods, like primary products other than agricultural products and basic manufactured goods will be competitively priced. This situation benefits consumers in industrialized countries who are purchasing these imports. On the other hand, the WTO's anti-competitive market regime, embodied in the TRIPS Agreement, requires members to prohibit competition, benefiting exporters of protected products in industrialized countries. The developing countries find that their export prices are not rising, but the cost of imported goods, especially manufactured products, drugs, sound recordings, film, and video is constantly rising. As a result their terms of trade, the price of exports over imports, are continually declining, leading to shortages of foreign exchange, and stifling economic growth.

\section{E. Are Antidumping Duties and Countervailing Duties an Appropriate Response to External Market Failures and Distortions?}

According to the theory of the second best, an importing country should respond to an external market failure or distortion with a restriction on imports that would effectively neutralize the externality by raising the price of the import. Arguably, that is the reason that the GATT authorizes WTO member states to impose antidumping or countervailing duties on imports if an importing country determines that the imports, either by reason of dumping or subsidies, are being sold at a price below normal value. ${ }^{112}$

Antidumping and countervailing duties may appear justifiable, rather

112. GATT, supra note 80 , art. VI. 
than protectionist, because the exporter is either engaged in predatory pricing or has received a subsidy that allows it to compete unfairly. In reality, however, most antidumping and countervailing duties are disguised protectionism.

Antidumping duties are not justifiable and are distorting. Rational producers do not sell goods below the cost of marginal production, because they could not stay in business for very long if they did so. In certain circumstances a rational producer might sell goods below the marginal cost, for example, if the goods would otherwise perish. However, even in these rare circumstances, predatory pricing occurs only for a short duration. A foreign producer that tries to drive competitors out of business with predatory pricing may find that as soon as its predation ceases, new producers will enter the market. A better way to police predation is through competition laws.

Arguably, there is a greater risk of predatory pricing in foreign trade than in domestic commerce, because of the possibility that a producer can charge high prices in one country to subsidize lower prices in another country. Such price discrimination is only possible if there are barriers to trade that would prevent a smart purchaser from re-exporting the lower-priced good to the high-priced market. The benefits to consumers from lower-priced imports almost always will outweigh the harm to competing domestic producers when imports are dumped. If there are barriers to trade, the appropriate prescription should be to eliminate those barriers, rather than compounding the distortion by imposing dumping duties.

The GATT's provisions on dumping invite protectionist behavior, because they delegate to importing countries broad discretion to determine when goods are being sold at less than the normal value, whether the imports cause a material injury, how much antidumping or countervailing duty is appropriate, and when to remove the duties. These determinations are largely discretionary and often capricious. ${ }^{13}$ For example, in determining whether imports sold below normal value are causing injury, the Agreement on Dumping gives the importing government broad discretion to judge whether an injury has occurred

113. The 1994 Agreement on Dumping tried to limit the discretion of states to some extent, and recent decisions by the Appellate Body have also clarified some of these provisions. Some recent decisions by the WTO Appellate Body have tried to cut back some of the discretion states exercise in antidumping measures. See, e.g., European Communities-Anti-Dumping Duties on Imports of Cotton-Type Bed Linen from India, WT/DS141/AB/R, 2001 WTO DS LEXIS 13 (WTO Mar. 1, 2001), United States-Anti-dumping Measures on Certain Hot-Rolled Steel Products from Japan, WT/DS184/AB/R, 2001 WTO DS LEXIS 34 (WTO July 24, 2001). Nevertheless, importing states still exercise a high degree of subjectivity in imposing duties. 
and whether it was caused by the import "based on an examination of all relevant evidence." 114 In the absence of any objective criteria for determining injury or causation, this analysis often comes down to the "gut feelings" of the national authorities. Dumping exists if the "normal value" of a good in the exporting country's market is greater than the "export price" for which it is sold to the importer. The amount of the difference is used to calculate the amount of the dumping duty. The import-competing domestic producers will want to persuade the national authorities that the normal value is as high as possible and that the export price is as low as possible in order to maximize the amount of the dumping duty. The Agreement on Dumping allows the importing government discretion to determine the "normal value" and the "export price" of the import. To determine the normal value of an import, the importing government can look at either the price in the home market, or if it is not satisfied that the home market price is representative, the price in a third-country market or a price that it constructs from whatever information it selects on the costs of production either in the home market or in another market. ${ }^{115}$ These calculations bear no relationship to the question whether a foreign producer is engaged in predatory pricing.

Countervailing duties are another form of disguised protectionism. The calculation of a countervailing duty also involves a high degree of discretion. The Agreement on Subsidies and Countervailing Measures (SCM) does not define a subsidy with precision; so importing governments have some discretion to decide whether a foreign government's actions are a subsidy. There is no prescribed method for calculating the size of the subsidy or its effect on the price of an import. For example, consider how $\$ 1$ million in subsidies would affect the price of the exporter's product? Does the subsidy affect the price of all the exporter's products or only a specific product line? Does it affect the price of exports the same as the price of goods destined for the home market? Does the effect of the subsidy linger over time? Is the effect the same in year one as in year ten, or does the benefit of a subsidy to the product rise or fall depending upon the state of technology or the condition of capital equipment? The Agreement on SCM leaves the answer to these questions in large measure up to the discretion of the importing government's trade authorities.

Between 1995-2001, members had in force 1,066 antidumping duties

114. Agreement on the Implementation of Article VI of the General Agreement on Tariffs and Trade 1994 [hereinafter Agreement on Dumping], at 173, art. 3.5.

115. Id. at 168-72, art. 2. 
and 78 countervailing duties. ${ }^{116}$ The United States alone had imposed 169 antidumping measures and 31 countervailing duties. These statistics probably understate the distorting influence of dumping and countervailing duties on markets. When a domestic industry files an antidumping or countervailing duty petition against the importer, there is a complex and costly administrative proceeding that may result in a duty that prevents the importer from selling in the import market. The mere threat of such actions has a tendency to deter import competition and raise prices for consumers. Import-competing businesses can drive imports out of the U.S. market merely by initiating a petition for antidumping or countervailing duties. Importers are constantly aware of the threat of a dumping or countervailing duty action, and this threat acts as a deterrent against aggressive pricing policies. In this way the existence of these import laws discourages competitive pricing and distorts market forces.

\section{F. Summary}

In sum, there is much less than meets the eye to the GATT's prohibition on discriminatory trade measures. These broad and narrow exceptions are employed so frequently that the appearance of a freetrade regime is illusory. The WTO represents a system of managed trade in which states continue to play a very significant role in determining the market. What has been described in the structure of the GATT as "embedded liberalism," 117 is in fact a more complex and incoherent system of protectionism, preferences, and anti-competitive rules that create a wide range of market distortions and prevent states from correcting market failures. As a result, the GATT may yield an inefficient allocation of resources and reduce economic growth.

The proponents of international trade institutions are right to advocate for institutions like the WTO, but not because trade institutions promote economic growth. Although these institutions may not necessarily create economic growth or development and may in fact distort the economic policies of member states, they still serve an important political function. International trade institutions are vital to policy coordination and dispute resolution, which is discussed in Part IV.

116. WTO, WTO Statistics: anti-dumping measures, countervailing measures, and safeguard measures from 1/1/95-12/31/01, at http://www.wto.org/english/tratop_e (last visited Oct. 18, 2002).

117. See generally, John Gerard Ruggie, International Regimes, Transactions, and Change: Embedded Liberalism in the Postwar Economic Order, 36 INT'L ORG. 36 (1982). 


\section{How INTERNATIONAL TRADE INSTITUTIONS CONTRIBUTE to POLICY COORDINATION AND DISPUTE RESOLUTION}

The WTO is not primarily an engine of economic growth, although it may contribute to competitive conditions in some markets. Contrary to the expectations of its proponents and the critics of international legal institutions generally, the WTO is effective as a political institution in resolving conflicts and providing a framework for cooperation and negotiation.

Once a WTO panel or the Appellate Body has found nullification and impairment, the DSB adopts the report and recommends that the offending party bring the measure into conformity within a reasonable time. (The DSB will only reject the report if there is a consensus of WTO members against it). The offending party can either comply or offer "compensation" in the form of lower-tariff rates for all WTO members. If the offending party fails to comply or compensate within a reasonable time, the complaining party can request authorization from the DSB to suspend or withdraw tariff concessions in an amount equivalent to the value of the GATT benefits that have been nullified or impaired. The suspension or withdrawal of tariff concessions are essentially bilateral trade sanctions to compel compliance with the DSB ruling. Once the amount of trade sanctions is determined, the DSB automatically authorizes sanctions, unless a consensus of the WTO members objects. As many critics have noted, the DSB lacks a strong enforcement measure. The reliance on suspending trade concessions is merely a form of self-help that is unlikely to compel compliance. Most states do not have the leverage to coerce other states to comply with DSB rules. Perhaps only the EU, Japan, China, and the United States have sufficient leverage to enforce DSB rulings.

Commentators have leveled numerous criticisms at the WTO's dispute-settlement procedure. One criticism is that the DSB disrespects national sovereignty, particularly with regard to environmental, health, and safety regulations, or for lacking transparency. ${ }^{118}$ These critics view the DSB as trying to legislate new rules through the dispute-settlement process without proper legal authority under the WTO Charter or political support from member states. ${ }^{119}$ A second criticism is that the

118. E.g., Paul Stephan, American Hegemony and International Law: Sheriff or Prisoner? The U.S. and the World Trade Organization, 1 U. CHI. J. INT'L L. 49, $52-56$ (2000); Dispute Settlements in the WTO: Hearings before the Subcommittee on International Trade of the Committee on Finance U.S. Senate, 106th Cong., 58-69 (2000) (prepared statement of Lori Wallach, director of Public Citizen's Global Trade Watch).

119. Claude E. Barfield, Free Trade, Sovereignty, Democracy: The Future of the World 
DSB does not have enough authority to be effective. It relies on bilateral, rather than multilateral sanctions. Only large industrialized states, primarily the United States, Japan, and the European Union, have sufficient leverage to compel compliance from other weaker economies. One solution would be to require offending states to compensate all states by unilaterally lowering tariff barriers. ${ }^{120} \mathrm{~A}$ third related criticism is that the dispute settlement process is biased in favor of most industrialized countries, and that when developing countries resort to the DSB they obtain less favorable outcomes.

These critics take for granted the overall success rate of the WTO dispute-settlement process. The average annual number of complaints filed with the WTO since 1994 is about 30 , which is about double the number of complaints filed with GATT during the five years preceding the WTO. ${ }^{121}$ The dramatic increase in the number of cases occurred as a result of the increased obligations undertaken under the Uruguay Round Agreements, and the extension of the multilateral agreements to the developing countries, which were previously not parties to many of these agreements. In fact, the most significant change in the composition of these cases is the increased number of cases brought against the developing countries. ${ }^{122}$ WTO members have readily resorted to the dispute-settlement process, even in cases that are highly contentious and unlikely to be resolved by a panel decision.

Relatively few DSB cases have reached the stage of requiring some form of trade sanctions. As of November 1, 2002, WTO members have notified the DSB of 273 complaints or matters, including all requests for consultations, most of which were settled without dispute-resolution proceedings. As of November 1, there were still 16 matters pending panel or appellate review proceedings, and there were 63 reports adopted by panels or the Appellate Body. In 39 matters the parties reached mutually-agreed solutions, and in 24 matters the offending measure or the panel request was withdrawn without requiring a compliance proceeding. There have been ten compliance reports adopted by a panel or the Appellate Body. Five of these resulted in arbitration proceedings on the level of concessions to be suspended, and only in five matters has the WTO authorized the suspension of

Trade Organization, 2 U. CHI. J. INT'L L. 403, 408 (2001).

120. Joost Pauwelyn, Enforcement and Countermeasures in the WTO: Rules are Rules-Toward a More Collective Approach, 94 AM. J. INT'L L. 335, 343-45 (2000).

121. Robert E. Hudec, The New WTO Dispute Settlement Procedure: An Overview of the First Three Years, 8 MINN. J. Global TRADE 1, 15-16 (1999).

122. Id. at $18-25$. From $1980-1994$, only $13 \%$ of the complaints were filed against developing countries. From $1995-1998,39 \%$ of the complaints were against developing countries. Id. at 24 . 
concessions. ${ }^{123}$ In sum, out of 273 complaints, only five have remained unsettled and subject to trade sanctions. ${ }^{124}$

Admittedly, some parties may have abandoned their complaint because they did not believe that they had sufficient leverage to compel compliance, or they may have feared retaliation. Still, it is a remarkable record of compliance, especially for an international organization in its infancy. If we pose the question what might have happened if the WTO did not exist, it is very likely that a number of these 273 trade disputes would have resulted in a spiral of retaliation that would have ended in a trade war. It is also probable that diplomatic relations between states would have suffered from economic tensions. ${ }^{125}$

The aggregate record of complaints might be viewed as unimpressive if we assumed that most of the cases were brought by, or against, countries without market leverage. We might assume that these countries were compelled to settle disputes precisely because of the absence of any effective enforcement mechanism. In fact, a very high percentage of the cases were brought by, or against, the United States or the EU, and even these major trading powers often felt compelled to reach a settlement or to comply with a report by a panel or the Appellate

123. WTO, Update of WTO Dispute Settlement Cases, WT/DS/OV/9 (Oct. 25, 2002), available at http://www.wto.org. Cf. Steve Charnovitz, Rethinking WTO Trade Sanctions, 95 AM. J. INT'L L. 792, 794 (2001). As of this date, sanctions have only been implemented by the United States against the EU in the meat hormones and banana matters.

124. Those five enforcement actions concerned the EU ban on meat hormones, the EU import licensing scheme for bananas, the U.S. Foreign Sales Corporation tax provisions, Brazil's export subsidies for aircraft, and Canada's aircraft subsidies. In the Banana decision, the DSB authorized the United States to suspend tariff concessions worth $\$ 191$ million after the EU failed to comply within fifteen months of its decision. European Communities--Regime for the Importation, Sale and Distribution of Bananas, WTO Doc. WT/DS27/ARB (Apr. 9, 1999), available at http://www.wto.org. Two years after the United States imposed $100 \%$ tariffs on certain EU imports, the European Union and the United States settled their dispute. In the Meat Hormones decision, the DBS authorized the United States to impose \$116 million in tariffs and authorized Canada to impose Can.\$11 million on selected EU imports after the EU failed to comply within fifteen months of its decision. European Communities-Measures Concerning Meat and Meat Products (Hormones), WTO Doc. WT/DS26/ARB (July 12, 1999), available at http://www.wto.org. Negotiations between the U.S. and the EU over meat hormones is continuing. In the Foreign Sales Corporation matter, the DSB authorized the EU to impose up to $\$ 4$ billion in tariffs on certain EU imports, but the EU and the United States are continuing negotiations aimed at amending U.S. tax provisions to conform to the WTO ruling. As of March 2003 , it seems likely Congress will repeal the offending tax provision. Finally, the twin complaints against aircraft subsidies brought by Canada and Brazil against each other have resulted in a draw. Neither party has implemented sanctions against the other.

125. See Dispute Settlements in the WTO: Hearing Before the S. Finance Comm., 105th Cong. 35-36, 41 (2000) (prepared statement of Ambassador Charlene Barshefsky, U.S. Trade Rep.); U.S. Interests and Experience in the WTO Dispute Settlement System: Hearing Before the S. Finance Comm., Subcomm. on Int'l Trade, 106th Cong. 20-22, 52-54, 57 (2000) (testimony and prepared statement of John H. Jackson, Georgetown Law Center)). 
Body. As of 2000 , the United States brought $30 \%$ of all the complaints reported to the DSB, and the United States defended against $25 \%$ of all the complaints reported. ${ }^{126}$ As of April 2000, the United States was a plaintiff in 56 cases and a defendant in 38 cases. ${ }^{127}$ As a plaintiff, the United States prevailed in 13 cases and lost 2 out of 25 cases completed as of March 2000. As a defendant, the United States prevailed only once, and lost 6 out of 17 cases completed. ${ }^{128}$ In two of the cases brought against the United States the United States agreed to amend U.S. law. ${ }^{129}$ In three other cases the United States agreed to change regulations or guidelines. ${ }^{130}$

The threat of trade sanctions is insufficient to explain this record of compliance. In its young life the WTO has already succeeded in creating a culture of legitimacy in which member states perceive that the benefits of membership and support for the organization's disputesettlement procedures justifies complying with recommendations for policy changes. Even in the absence of enforcement measures, the United States felt compelled to change its behavior. If the disputesettlement process is sufficient to compel compliance from the world's most powerful trading nation in most cases, then a fortiori it is sufficient to compel compliance from other countries.

Among developing and transitional economies, the WTO regime may contribute momentum towards greater political and economic openness. To maintain open markets and attract foreign investment these governments may need to satisfy certain expectations of the international community. Arguably, the market generally may avoid countries with extreme human rights violations, political corruption, terrorism, or instability. However, there are examples, like Allende's Chile or China, which suggest to the contrary that the market may be indifferent to human rights violations. In any event, there is no evidence

126. General Accounting Office, GAO/T-NSIAD/OGC-00-202, World Trade Organization: U.S. Experience in Dispute Settlement System: The First Five Years 3-4 (June 20, 2002) (testimony of Susan S. Westin before the Subcommittee on International Trade, Senate Committee on Finance), available at http://www.gao.gov/new.items/n700202t.pdf.

127. Id.

128. Id. at 5 .

129. The United States amended a 1996 law for determining the country of origin of imported textiles, and the United States agreed to ask Congress for authority to waive Title IV of the Helms-Burton Act. General Accounting Office, GAT/T-NSIAD/OGC-00-202, U.S. Experience in Dispute Settlement System: The First Five Years 7 (June 20, 2002) (testimony of Susan S. Westin), available at http://www.gao.gov.

130. The EPA changed a Clean Air Act regulation of gasoline standards to accommodate foreign suppliers, the Department of Commerce changed a standard for lifting an antidumping order, and the State Department revised its certification guidelines for enforcing the U.S. ban on imported shrimp harvested using nets that endanger sea turtles. Id. at 7-8. 
that in the absence of trade, a government is more likely to reform itself, and there is much evidence that public opinion and investor caution may eventually encourage some reform.

The regional trade blocs illustrate how the inducement of trade may encourage internal reforms. For example, since the adoption of NAFTA, Mexico has matured into a true multi-party democracy. The Mexican Government has taken significant steps both to liberalize the economy, and in the process, to root out political corruption. The increased economic relationship to the United States and Canada has closely tied Mexico to the liberal democratic system. Support for the political center has grown stronger. One can argue that NAFTA has brought both democracy and political stability to Mexico. On the other hand, Mexican economic reforms have led to the displacement of large numbers of rural farmers who may be a source of political and social unrest in the future.

Similarly, the lure of access to the EU's markets has promoted political reform in other European states. The nationalist government in Hungary stepped back from its national claims to Transylvania in part to avoid problems with its admission to the EU. In Poland the government has continued to press political reforms and resisted nationalist pressures to win EU membership. Turkey has made progress toward improving its human rights situation in order to win EU admission.

To some extent the EU has had a tempering effect on the politics of its current member states as well, although globalization has been a twoedged sword in this regard. Right-wing nationalist groups have shown surprising strength in recent elections in the Netherlands, France, Austria, and Germany, and their support is largely a response to globalization and increased immigration, in particular. Yet, each time a nationalist candidate gains strength, there is a countervailing response from the EU. Other EU members harshly criticized Le Pen's victory in the first-round of the French election and the implicit threat of some form of isolation contributed to the overwhelming vote against Le Pen in the second-round of elections. Concern about the reaction of the EU also has helped to weaken nationalist parties in Germany, Austria, and the Netherlands.

In sum, the WTO and the regional trade blocs have minimized conflicts between states, promoted political and economic reforms, and stabilized national governments. Perhaps, the dispute-resolution process should be made stronger and more binding on states. Still, the WTO's record of dispute settlement is solid evidence that international trade institutions, even in the absence of an enforcement authority, can be 
remarkably effective.

\section{CONCLUSION}

Globalization's proponents justify international trade institutions as engines of economic growth and development. There is no theoretical basis or empirical evidence to support that proposition. Comparative advantage is irrelevant to most international markets. Trade yields marginal static gains, which are likely to be cancelled out by sunk costs from lost human and financial capital and social costs from import competition. Moreover, trade has contributed to global income inequality, and there is no sign that governments are prepared to redistribute the benefits of trade more equitably. As a result, social welfare on a global scale may be diminished by trade.

International trade institutions, in particular the GATT, have distorted market forces in a variety of ways. Contrary to the prescriptions of neoliberalism, in certain respects, GATT prohibits states from correcting market distortions and market failures. It also legitimates a range of protectionist measures that further distort the allocation of resources. By requiring protection for intellectual property rights, TRIPS has created two quite distinct tiers of trade regulation: a relatively competitive market for the exports of developing countries and a non-competitive market for the patented and copyrighted exports of industrialized countries. As a result, developing countries face declining terms of trade.

Despite these criticisms, there is substantial evidence that international trade institutions are effective in reducing conflict, coordinating trade policy, and stabilizing governments. As economic engines institutions like the WTO and the NAFTA may be abject failures, but as political policymaking institutions, they have succeeded brilliantly.

If globalization is the new world order, then international trade institutions are its political capitals. Advocates of human rights, labor standards, and the environment rightly petition these political institutions for some redress from globalization's harms. Though opponents of linkage dismiss these claims by asserting that international trade institutions have a limited jurisdiction, their arguments ring false. The WTO is more than a mechanical application of principles of market rationality. The WTO has inscribed a wide range of policy choices onto its member states, even in ways that distort market forces.

Globalization has stirred deep discontent and passion around the 
globe. International trade institutions cannot retreat behind a curtain of market rhetoric to defend their actions. Responsibility follows from power. These institutions should acknowledge their political character and accept responsibility for the human consequences of globalization. 